BMC

Microbiology

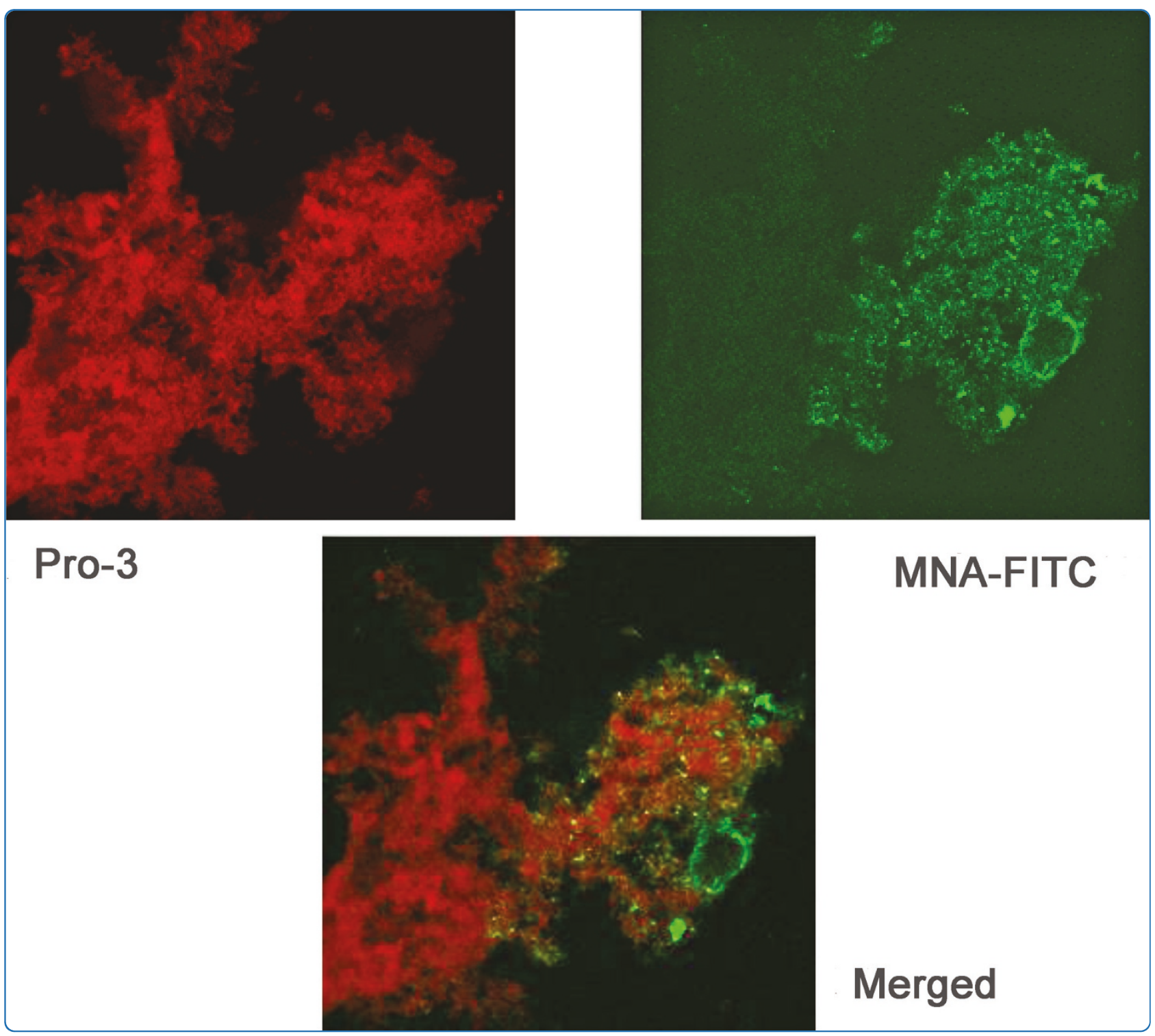

Identification, structure, and characterization of an exopolysaccharide produced by Histophilus somni during biofilm formation

Sandal et al. 


\title{
Identification, structure, and characterization of an exopolysaccharide produced by Histophilus somni during biofilm formation
}

Indra Sandal ${ }^{1,5+}$, Thomas J Inzana ${ }^{1 *+}$, Antonio Molinaro ${ }^{2}$, Christina De Castro ${ }^{2}$, Jian Q Shao ${ }^{3}$, Michael A Apicella ${ }^{3}$, Andrew D Cox ${ }^{4}$, Frank St Michael ${ }^{4}$ and Gretchen Berg ${ }^{1,6}$

\begin{abstract}
Background: Histophilus somni, a gram-negative coccobacillus, is an obligate inhabitant of bovine and ovine mucosal surfaces, and an opportunistic pathogen responsible for respiratory disease and other systemic infections in cattle and sheep. Capsules are important virulence factors for many pathogenic bacteria, but a capsule has not been identified on H. somni. However, H. somni does form a biofilm in vitro and in vivo, and the biofilm matrix of most bacteria consists of a polysaccharide.

Results: Following incubation of $\mathrm{H}$. somni under growth-restricting stress conditions, such as during anaerobiosis, stationary phase, or in hypertonic salt, a polysaccharide could be isolated from washed cells or culture supernatant. The polysaccharide was present in large amounts in broth culture sediment after $\mathrm{H}$. somni was grown under low oxygen tension for 4-5 days (conditions favorable to biofilm formation), but not from planktonic cells during log phase growth. Immuno-transmission electron microscopy showed that the polysaccharide was not closely associated with the cell surface, and was of heterogeneous high molecular size by gel electrophoresis, indicating it was an exopolysaccharide (EPS). The EPS was a branched mannose polymer containing some galactose, as determined by structural analysis. The mannose-specific Moringa M lectin and antibodies to the EPS bound to the biofilm matrix, demonstrating that the EPS was a component of the biofilm. The addition of $\mathrm{N}$-acetylneuraminic acid to the growth medium resulted in sialylation of the EPS, and increased biofilm formation. Real-time quantitative reverse transcription-polymerase chain reaction analyses indicated that genes previously identified in a putative polysaccharide locus were upregulated when the bacteria were grown under conditions favorable to a biofilm, compared to planktonic cells.

Conclusions: $\mathrm{H}$. somni is capable of producing a branching, mannose-galactose EPS polymer under growth conditions favorable to the biofilm phase of growth, and the EPS is a component of the biofilm matrix. The EPS can be sialylated in strains with sialyltransferase activity, resulting in enhanced density of the biofilm, and suggesting that EPS and biofilm formation may be important to persistence in the bovine host. The EPS may be critical to virulence if the biofilm state is required for $\mathrm{H}$. somni to persist in systemic sites.
\end{abstract}

\section{Background}

Histophilus somni (Haemophilus somnus) is a host-specific, gram-negative coccobacillus, and an opportunistic pathogen of cattle and sometimes sheep that is responsible for a variety of systemic infections, including

\footnotetext{
*Correspondence: tinzana@vt.edu

+ Contributed equally

${ }^{1}$ Center for Molecular Medicine and Infectious Diseases, Virginia-Maryland Regional College of Veterinary Medicine, Virginia Tech, Blacksburg, Virginia, USA

Full list of author information is available at the end of the article
}

meningoencephalitis, pneumonia, myocarditis, septicemia, and reproductive failure [1,2]. Hallmarks of $H$. somni infection include septicemia, by which the organism can disseminate to various tissues such as the brain, heart, and joints [1-3], and adherence to and inflammation of vascular endothelial cells $[4,5]$. Pathogenic isolates of $H$. somni share many virulence attributes with human-specific mucosal pathogens that are designed to resist host defense mechanisms. For example, the structure of the lipooligosaccharide (LOS) of H. somni is remarkably similar to that of Neisseria gonorrhoeae,
C Biomed Central

() 2011 Sandal et al; licensee BioMed Central Ltd. This is an Open Access article distributed under the terms of the Creative Commons Attribution License (http://creativecommons.org/licenses/by/2.0), which permits unrestricted use, distribution, and reproduction in any medium, provided the original work is properly cited. 
including an outer core that mimics the structure of lacto- $N$-neotetraose on the glycosphingolipid of mammalian cells [6-8]. Furthermore, like Haemophilus influenzae, the $H$. somni LOS outer core undergoes a high rate of phase variation due to variable number tandem repeats in the genes that encode for the LOS glycosyl transferases $[9,10]$; the LOS is also decorated with $N$ acetylneuraminic acid (Neu5Ac or sialic acid) and phosphorylcholine, which can contribute to resistance to host defenses and adaptation to specific host sites $[11,12]$. Other $H$. somni virulence attributes include immunoglobulin binding proteins [13,14], cell adhesions [3], resistance to the bactericidal activity of serum [15], survival in and inhibition of the oxidative burst of phagocytic cells [16-19], toxicity to epithelial cells [20,21], and induction of apoptosis of endothelial cells [22-24]. However, a few strains that have been isolated from the genital tract are serum-sensitive and less virulent or avirulent [15]. Determination of the genome sequence of $H$. somni avirulent strain $129 \mathrm{Pt}$ from the healthy bovine prepuce [25], and 2336 from bovine pneumonia (sequence accession number NC_010519) revealed many genetic deletions and insertions that may be associated with differences in the virulence of these two strains.

Many species in the family Pasteurellaceae are encapsulated, including Haemophilus influenzae, H. parasuis, Actinobacillus pleuropneumoniae, Mannheimia haemolytica, and Pasteurella multocida. However, H. somni has been reported to be nonencapsulated, based on ruthenium red staining and electron microscopy $[1,26,27]$. Nonetheless, Miller et al. [28] reported the presence of a polysaccharide other than LOS in $H$. somni cultures, although the composition and relationship of this polysaccharide to $H$. somni was not determined. The capability of $H$. somni to produce a biofilm under growth conditions that favor low oxygen tension and low shear forces has been described [29], but the composition of the matrix making up the biofilm is not yet well characterized. In most bacteria the biofilm matrices normally consist largely of polysaccharide [30].

A comparative analysis of extracts from cells grown anaerobically and in a candle extinction jar revealed the presence of a polysaccharide in anaerobic extracts only. Subsequently it was determined that the polysaccharide could be efficiently purified from broth cultures grown to late stationary phase under low aeration conditions favorable to biofilm formation [29]. We have determined that this high molecular weight polysaccharide from $H$. somni is a branched mannose polymer, and a component of the $H$. somni biofilm. Following genome sequencing of $129 \mathrm{Pt}$ and 2336, putative genes that may be responsible for production of this polysaccharide were identified [[25], Siddaramappa S CJ, Duncan AJ, Gillaspy AF, Carson M, Gipson J, Gipson M, Orvis J, Zaitshik J,
Barnes G, Brettin TS, Bruce D, Chertkov O, Detter JC, Han CS, Tapia R, Thompson LS, Dyer DW, Inzana TJ: Genome sequence of Histophilus somni strain 2336 from bovine pneumonia and comparison to commensal strain $129 \mathrm{Pt}$ reveals extensive horizontal gene transfer and evolution of pathogenesis. Submitted]. Most of these genes were found to be upregulated under conditions that favor biofilm formation.

\section{Methods}

\section{Bacterial strains and growth conditions}

H. somni 2336 is a pathogenic isolate from bovine pneumonia, 738 is an LOS phase variant of 2336 obtained following subculture and passage in a bovine, and $129 \mathrm{Pt}$ is a non-pathogenic commensal from the healthy bovine prepuce [15]. The bacteria were grown on Columbia agar with $5 \%$ sheep blood (CBA) in $3-5 \% \mathrm{CO}_{2}$, in Columbia broth, or Terrific broth (Difco, BD Diagnostic Systems, Sparks, MD); the latter two supplemented with $0.1 \%$ Trizma base (no $\mathrm{pH}$ adjustment), $0.01 \%$ thiamine monophosphate (TMP) [31] (CTT or TTT, respectively), and $1 \%$ glucose. The bacteria were grown at $37^{\circ} \mathrm{C}$ or $42^{\circ}$ $\mathrm{C}$ with rapid shaking $(\sim 200 \mathrm{rpm})$ in flasks with a large headspace and harvested in early stationary phase $(\sim 5 \times$ $10^{9}$ colony forming units $\left.[\mathrm{CFU}] / \mathrm{ml}\right)$. Alternatively, the bacteria were grown under low oxygen tension in a bottle filled with medium to minimize the headspace and shaken slowly (75 rpm) to favor biofilm formation [29]. Bacteria were also grown in a strict anaerobic environment on CBA in a BD GasPak system (BD Diagnostic Systems), or in CTT containing Oxyrase for Broth ${ }^{\mathrm{TM}}$ (Oxyrase, Mansfield, OH). For some experiments, the medium was supplemented with $2 \% \mathrm{NaCl}$, or the bacteria were harvested during mid- to late-stationary phase (48-72 h post-inoculation). For growth supplementation with Neu5Ac, $1 \mathrm{mg}(50-\mu \mathrm{g} / \mathrm{ml}$ final concentration) of Neu5Ac (Sigma Chemical Co.) was added to CBA, TTT, or to a chemically defined medium [31].

\section{Polysaccharide purification}

H. somni was grown on CBA plates incubated in $5 \%$ $\mathrm{CO}_{2}$ or anaerobic conditions for $48-72 \mathrm{~h}$ at $37^{\circ} \mathrm{C}$. The cells were scraped from the plates and suspended in phosphate buffered saline, $\mathrm{pH}$ 7.2, (PBS) to a turbidity of 150 Klett units (about $10^{9} \mathrm{CFU} / \mathrm{ml}$ ). After vigorous vortexing at room temperature, the cell suspension was incubated at $37^{\circ} \mathrm{C}$ for $1 \mathrm{~h}$, vortexed again, and the cells removed by centrifugation $(10,000 \times g$ for $15 \mathrm{~min})$. Cetavlon (hexadecyltrimethyl ammonium bromide) was added to a final concentration of $0.005 \mathrm{M}$. Any precipitate that formed was harvested and solubilized in distilled water. No further purification was done on this sample. Alternatively, the bacteria were grown to late stationary phase in CTT (48-72 $\mathrm{h}$ post-inoculation), the 
bacteria harvested as above, and Cetavlon added to the supernatant. Any precipitate that formed following addition of Cetavlon was further purified by enzyme digestion (RNase, DNase, and Proteinase K), phenol extraction, and ultracentrifugation to remove LOS, as described for purification of the capsular polysaccharide of Actinobacillus pleuropneumoniae [32].

The bacteria were also grown at $37^{\circ} \mathrm{C}$ in filled 1-L bottles containing TTT with shaking at $75 \mathrm{rpm}$ for 4-5 days. The clear supernatant was carefully removed and the sediment was extracted with $45 \%$ aqueous phenol at room temperature, digested with DNase, RNase, and Proteinase $\mathrm{K}$, and subjected to ultracentrifugation at $125,000 \times g$ at $4^{\circ} \mathrm{C}$, as described for purification of $H$. somni LOS [33], except that the supernatant from the ultracentrifugation step was retained. Polysaccharide in the supernatant was precipitated by the addition of 30 $\mathrm{mM}$ sodium acetate (final) and 5 volumes of cold $\left(-20^{\circ}\right.$ C) $95 \%$ ethanol, and incubated at $-20^{\circ} \mathrm{C}$ for at least 4 hours. The pellet obtained by centrifugation was suspended in distilled water, and eluted through a Sephacryl S-400 column $(2.5 \times 50 \mathrm{~cm})$ with distilled water as eluent. The first fractions containing carbohydrate (determined by phenol-sulfuric acid assay) [34] were pooled and lyophilized.

For comparative analysis of polysaccharide production under various environmental conditions, the bacteria were cultured in CTT at $37^{\circ} \mathrm{C}$ either anaerobically (with Oxyrase) or with $2 \% \mathrm{NaCl}$ aerobically, or at $42^{\circ} \mathrm{C}$ aerobically. All cultures were grown to $4 \times 10^{9} \mathrm{CFU} / \mathrm{ml}$ (early stationary phase). The bacteria were harvested and 0.005 M Cetavlon (final concentration) was added to the supernatants to precipitate large molecular mass, negatively charged components. The precipitate was then solubilized with $0.9 \mathrm{M} \mathrm{NaCl}, 5$ volumes of cold ethanol were added, and the mixture incubated at $-20^{\circ} \mathrm{C}$ overnight. The precipitate was resuspended in water, lyophilized, and weighed to determine the amount of polysaccharide in each sample. The cell pellets were washed with PBS and the concentration of protein in each sample was determined by BCA protein assay (Pierce, Rockford, IL).

\section{Polyacrylamide gel electrophoresis and alcian blue silver staining}

Polyacrylamide gel electrophoresis (PAGE) for polysaccharides was done as described by Pelkonen et al. [35], followed by alcian blue and silver staining by a modified method of Min and Cowman [36] using a Bio-Rad silver stain kit.

\section{Immune serum}

Rabbits were immunized subcutaneously in 4 different sites with a total of $50 \mu \mathrm{g}$ of purified polysaccharide (in
$1 \mathrm{ml}$ of sterile water) mixed 1:1 with Freund's Complete Adjuvant, followed by a second immunization 3 weeks later with the same formulation of $50 \mu \mathrm{g}$ of polysaccharide in Freund's Incomplete Adjuvant. The rabbits were then immunized intravenously with $50 \mu \mathrm{g}$ of the polysaccharide until high-titer immune serum was obtained [37]. The IgG fraction of the antiserum was isolated by Protein A/G affinity chromatography [38].

\section{Immuno-transmission electron microscopy (ITEM) for analysis of polysaccharide on cells and in the biofilm}

To determine if the polysaccharide formed a well-associated structure around cells of $H$. somni, the bacteria were grown anaerobically or in $\mathrm{CO}_{2}$, and gently scraped off plates to a turbidity of 150 Klett units $\left(\sim 10^{9}\right.$ cells/ $\mathrm{ml}$ ). Immunofixation was done as previously described [39] using $1.5 \mathrm{ml}$ of bacterial suspension incubated for 1 $\mathrm{h}$ at $37^{\circ} \mathrm{C}$ with $1 \mathrm{ml}$ of a rabbit IgG $(0.3 \mathrm{mg} / \mathrm{ml})$ to the polysaccharide. Thin sections were examined with a JEOL 100 CX-II transmission electron microscope.

Biofilms were grown on coverslips in TTT to stationary phase [40], and fixed overnight in a 1-ml mixture of $4 \%$ paraformaldehyde and 5\% dimethyl sulfoxide. Samples were then embedded in situ in OCT (Sakura Finetek USA, Inc., Torrance, Calif.) on the coverslip surface upon which they were formed. For cryo-ITEM the coverslip was removed by freezing the sample in liquid nitrogen and shattering the glass, leaving the biofilm within the OCT. The OCT block was cut into $10 \mu \mathrm{m}$ thick sections using a Cryostat (MICROM HM 505E) [41].

OCT sections were washed with PBS, blocked with 5\% NGS (normal goat serum) (Electron Microscopy Sciences, Hatfield, PA) for $15 \mathrm{~min}$, and washed with PBS. The sections were incubated with a 1:25 dilution of polyclonal rabbit antiserum to the polysaccharide at $4^{\circ} \mathrm{C}$ overnight, washed with PBS, and incubated with the secondary antibody (goat anti-rabbit IgG) conjugated to 10-nm colloidal gold (Electron Microscopy Sciences) for 2 hours. The samples were subsequently washed in PBS, fixed in $2.5 \%$ glutaraldehyde in $0.1 \mathrm{M}$ sodium cacodylate buffer, treated with $1 \%$ osmium tetroxide, dehydrated through a graded series of ethanol $(30 \%, 50 \%, 70 \%)$, and flat-embedded in Spurr's resin using a Chien embedding mold (Polysciences, Niles, IL). Thin sections (70 nm) were cut with a Leica EM UC-6E ultramicrotome, collected on Formvar-coated nickel grids, and stained with uranyl acetate and lead citrate. The grids were dried and observed using a JEOL 1230 TEM.

\section{Scanning electron microscopy (SEM)}

H. somni 2336 and 129 pt were grown as a biofilm in chemically defined medium [31] with and without Neu5Ac $(50 \mu \mathrm{g} / \mathrm{ml})$ on glass coverslips in a 12 -well plate 
(Falcon 3911, Microtest), and incubated for 5 days at $37^{\circ}$ $\mathrm{C}$ without shaking. The coverslips were washed gently with PBS and fixed in $2.5 \%$ glutaraldehyde. The samples were processed as described [40], and examined using a Philips 505 scanning electron microscope.

\section{Lectin binding to biofilms}

The OCT resin sections were incubated with the fluorescein-conjugated Moringa M lectin (EY Laboratories, San Mateo, Calif.), which is specific for mannose, and counter-stained with the nucleic acid stain To-Pro3 (Molecular Probes, Invitrogen) as described [41]. The sections were washed in PBS three times, mounted with a coverslip, and examined by confocal laser scanning microscopy with red and green channels.

\section{Analytical and structural methods}

To determine if supplementation of cultures with Neu5Ac modified LOS under different culture conditions, LOS was extracted from bacteria grown as a biofilm, as planktonic cells, or on blood agar plates supplemented with and without Neu5Ac as previously described, and then O-deacylated (OdA LOS) (12). The OdA LOS samples were analyzed by negative ion electrospray mass spectrometry (ES-MS) on a VG Quattro triple quadrupole mass spectrometer (Fisons Instruments) with selective ion scanning at $m / z 290$, specific for Neu5Ac, as described previously [12].

To determine the presence of Neu5Ac on the polysaccharide from cells grown as a biofilm, polysaccharide purified from the biofilm ( $1 \mathrm{mg}$ ) was dried over $\mathrm{P}_{2} \mathrm{O}_{5}$ for $1 \mathrm{~h}$ under diminished pressure and treated with methanol $/ 2 \mathrm{M} \mathrm{HCl}$ at $80^{\circ} \mathrm{C}$ for $18 \mathrm{~h}$. The solution was extracted twice with equal volumes of $n$-hexane to remove contaminant fatty acid methyl esters, the methanolic phase was dried, and the $O$-methyl glycosides were acetylated with dry pyridine $(200 \mu \mathrm{l})$ and $\mathrm{Ac}_{2} \mathrm{O}(100 \mu \mathrm{l})$ at $80^{\circ} \mathrm{C}$ for $30 \mathrm{~min}$. The reactants were removed by evaporation, and the mixture of peracetylated $O$-methyl glycosides was analyzed by gas-liquid chromatographymass spectrometry (GLC-MS).

Sugar residues and their absolute configuration were determined by GLC and GLC-MS, which were carried out as described [8]. Monosaccharides were identified as acetylated $\mathrm{O}$-methyl glycoside derivatives. After methanolysis $\left(2 \mathrm{M} \mathrm{HCl} / \mathrm{MeOH}, 85^{\circ} \mathrm{C}, 24 \mathrm{~h}\right.$ ) and acetylation with acetic anhydride in pyridine $\left(85^{\circ} \mathrm{C}, 30 \mathrm{~min}\right)$ the polysaccharide sample was analyzed by GLC-MS. Linkage analysis was carried out by methylation, as described [42]. The sample was hydrolyzed with $4 \mathrm{M}$ trifluoroacetic acid $\left(100^{\circ} \mathrm{C}, 4 \mathrm{~h}\right)$, carbonyl-reduced with $\mathrm{NaBD}_{4}$, acetylated, and analyzed by GLC-MS.

For enzymatic hydrolysis of the polysaccharide, $10 \mathrm{mg}$ was dissolved in $50 \mathrm{mM} \mathrm{Na}^{+} \mathrm{CH}_{3} \mathrm{COO}^{-}(2 \mathrm{ml})$ and treated with $\alpha$-mannosidase $\left(200 \mu \mathrm{l}\right.$, Sigma) at $30^{\circ} \mathrm{C}$ for 7 days. After lyophilization the sample was fractionated through a $1.5 \times 100 \mathrm{~cm}$ column of Sephadex G-15 (Pharmacia), and eluted with $10 \mathrm{mM} \mathrm{NH}_{4} \mathrm{HCO}_{3}$ at a flow rate of $45 \mathrm{~mL} / \mathrm{h}$. Fraction volumes of $2 \mathrm{ml}$ were collected.

Acetolysis of mannan (30 mg) was performed as reported [43]. The acetylated products were applied to a column $(1 \times 150 \mathrm{~cm})$ of TSK-40, and eluted with distilled water at a flow rate of $14 \mathrm{ml} / \mathrm{h}$ at room temperature; $2.5 \mathrm{ml}$ fractions were collected. The fractionation yielded four fractions, as described in results.

Nuclear magnetic resonance (NMR) spectroscopy was used to obtain structural details of the polysaccharide. For structural assignments, $1 \mathrm{D}$ and $2 \mathrm{D}{ }^{1} \mathrm{H}-\mathrm{NMR}$ spectra were recorded from a solution of $2 \mathrm{mg}$ of polysaccharide in $0.5 \mathrm{ml}$ of $\mathrm{D}_{2} \mathrm{O}$, at $300 \mathrm{~K}$, at $\mathrm{pD} 7$, using a Bruker 600 DRX equipped with a cryo probe. The spectra were calibrated with internal acetone $\left[\delta_{\mathrm{H}} 2.225, \delta_{\mathrm{C}} 31.45\right] .{ }^{31} \mathrm{P}$ NMR experiments were carried out using a Bruker DRX-400 spectrometer, with aqueous $85 \%$ phosphoric acid used as an external reference (0.00 ppm). Rotating frame Overhauser enhancement spectroscopy (ROESY) data sets $\left(t_{1} \times t_{2}\right)$ were measured using $4096 \times 256$ points with a mixing time of $200 \mathrm{~ms}$. Double quantumfiltered phase-sensitive correlation spectroscopy (COSY) experiments were performed with $0.258 \mathrm{~s}$ acquisition time, using data sets of $4096 \times 256$ points. Total correlation spectroscopy experiments (TOCSY) were performed with a spinlock time of $100 \mathrm{~ms}$, using data sets $\left(t_{1} \times t_{2}\right)$ of $4096 \times 256$ points. In all homonuclear experiments the data matrix was zero-filled in the $F 1$ dimension to give a matrix of $4096 \times 2048$ points, and was resolution-enhanced in both dimensions by a sinebell function before Fourier transformation. Coupling constants were determined on a first order basis from $2 \mathrm{D}$ phase-sensitive double quantum filtered correlation spectroscopy (DQF-COSY) [44]. Heteronuclear single quantum coherence (HSQC) and heteronuclear multiple bond correlation (HMBC) experiments were measured in the ${ }^{1} \mathrm{H}$-detected mode via single quantum coherence with proton decoupling in the ${ }^{13} \mathrm{C}$ domain, using data sets of $2048 \times 256$ points. Experiments were carried out in the phase-sensitive mode. A $60 \mathrm{~ms}$ delay was used for the evolution of long-range connectivities in the HMBC experiment. In all heteronuclear experiments the data matrix was extended to $2048 \times 1024$ points using forward linear prediction extrapolation.

\section{Real-time quantitative reverse transcription PCR (qRT- PCR)}

Extraction of total RNA was performed from 3, 5, and 7 day-old biofilms using Total RNA Isolation (TRI) reagent (Molecular Research Centre, Inc., Cincinnati, 
$\mathrm{OH}$ ) [45]. Biofilms were grown in $1 \mathrm{~L}$ of broth as described above. The clear supernatant was carefully removed and the biofilm at the bottom of the flask was treated directly with TRI reagent following the manufacturer's protocol. To remove contaminating genomic DNA, approximately $10 \mu \mathrm{g}$ of RNA was treated using Qiagen's RNeasy on-column DNase I ( $Q$, 2.7 U DNase I/10 $\mu$ g RNA), followed by Qiagen RNeasy MinElute (for DNase I removal) according to the manufacturer's protocol. The RNA concentration was determined spectrophotometrically using a Nanodrop ND-1000 instrument (Nanodrop Technologies, Wilmington, DE), and the integrity of the RNA was assessed by agarose gel electrophoresis. Planktonic cells were collected after centrifugation $\left(6000 \times g\right.$ at $\left.4^{\circ} \mathrm{C}\right)$ and resuspended in TRI reagent for extraction of RNA. Cell pellets were stored at $-80^{\circ} \mathrm{C}$ until needed for RNA isolation.

Amplification, detection, and analysis of mRNA was performed using the ABI-Prism 7000 sequence detection system with a SYBR Green PCR master mix (Applied Biosystems, Carsbad, CA). The corresponding oligonucleotide primers were designed using Primer Express software (Applied Biosystems) and optimized for uniform size (90-100 bp) and consistent melting temperature $\left(55^{\circ} \mathrm{C}\right)$. For each set of primers, a standard amplification curve was plotted [critical threshold cycle $\left(C_{t}\right)$ against $\log$ of concentration] and only those with a slope of approximately -3 were considered reliable primers. SuperScript III First-Strand Synthesis System for qRT-PCR (Invitrogen; C The qRT-PCR reaction mixture contained $1 \times$ SYBR Green PCR master mix (Applied Biosystems), $1 \mu \mathrm{l} \mathrm{cDNA}$, and $0.5 \mu \mathrm{M}$ of the forward and reverse PCR primers. Initial denaturation was at $95^{\circ} \mathrm{C}$ for $10 \mathrm{~min}$, followed by a 40 -cycle amplification of denaturation at $95^{\circ} \mathrm{C}$ for $15 \mathrm{~s}$, and annealing and extension at $60^{\circ} \mathrm{C}$ for $1 \mathrm{~min}$. The critical threshold cycle, $\mathrm{C}_{\mathrm{t}}$, was defined as the cycle in which fluorescence becomes detectable above the background fluorescence, and is inversely proportional to the logarithm of the initial number of template molecules. A standard curve was plotted for each primer set with $C_{t}$ values obtained from amplification of known quantities of $H$. somni cDNA. The standard curves were used for converting the $\mathrm{C}_{\mathrm{t}}$ values into the relative number of cDNA molecules. Control reactions were used to determine any contamination by genomic DNA. The levels of expression of all genes tested by qRT-PCR were normalized using the housekeeping gene tryptophanyl-tRNA synthetase (trpS) of $H$. somni as an internal standard. There was no significant difference in the expression of the trpS under the different conditions or in the various samples tested (data not shown). Each assay was performed with three independent RNA samples in triplicate.

\section{Statistical analysis}

The Student's $t$ test was used to calculate the statistical differences between the mean levels of polysaccharide expression of experimental samples (biofilm grown cells) and control samples (planktonic cells). A $P$ value $<0.05$ was considered significant. All statistical analyses were done using InStat software (InStat, San Diego, CA).

\section{Results}

Identification of a novel $H$. somni surface component produced during anaerobic growth

To determine if there was variation in expression of membrane components under different environmental conditions, $H$. somni 738 was grown on CBA plates in $3-5 \% \mathrm{CO}_{2}$ or under anaerobic conditions for $48 \mathrm{~h}$ at $37^{\circ}$ $\mathrm{C}$. The bacteria were harvested from the plates as described in methods, and Cetavlon was added to the supernatant $(0.005 \mathrm{M}$, final concentration); LOS and protein-enriched outer membranes were prepared from the cell pellets $[46,47]$. No substantial qualitative differences were detected in the electrophoretic profiles of the LOS or membrane proteins of bacteria grown on CBA under $\mathrm{CO}_{2}$ or anaerobic conditions (data not shown), although growth of $H$. somni under anaerobic conditions was poor. Nonetheless, when Cetavlon was added to the supernatant of cells washed off CBA plates incubated under anaerobic conditions, a large precipitate formed, whereas little or no precipitate formed from the supernatant of cells grown on $\mathrm{CBA}$ in $\mathrm{CO}_{2}$ (data not shown). The Cetavlon precipitate was solubilized in distilled water, and greater than $90 \%$ of the precipitate was determined to be carbohydrate. However, it was not LOS, as determined by polyacrylamide gel electrophoresis and silver staining for LOS (data not shown). Electrophoresis of the Cetavlon precipitate followed by staining with alcian blue and ammoniacal silver demonstrated a heterogeneous profile, typical of high molecular size polysaccharide (Figure 1).

Immuno-transmission electron microscopy of $\mathrm{H}$. somni grown under anaerobic conditions or $\mathrm{CO}_{2}$

The polysaccharide from Cetavlon precipitates obtained from scaled up anaerobic cultures was further purified, as described in methods, and used to immunize a rabbit. The IgG from this antiserum was incubated with cells gently scraped off agar plates incubated in an anaerobic or $3-5 \% \mathrm{CO}_{2}$ atmosphere, and processed for ITEM. The Protein-A gold particles clearly bound to material that was shed from the cell surface and in relatively large quantities (Figure 2), indicating it was an exopolysaccharide (EPS). However, little of this material was produced by bacteria incubated in $\mathrm{CO}_{2}$ (Figure 2). Cells incubated with nonspecific IgG did not bind Protein-A gold particles (not shown). 


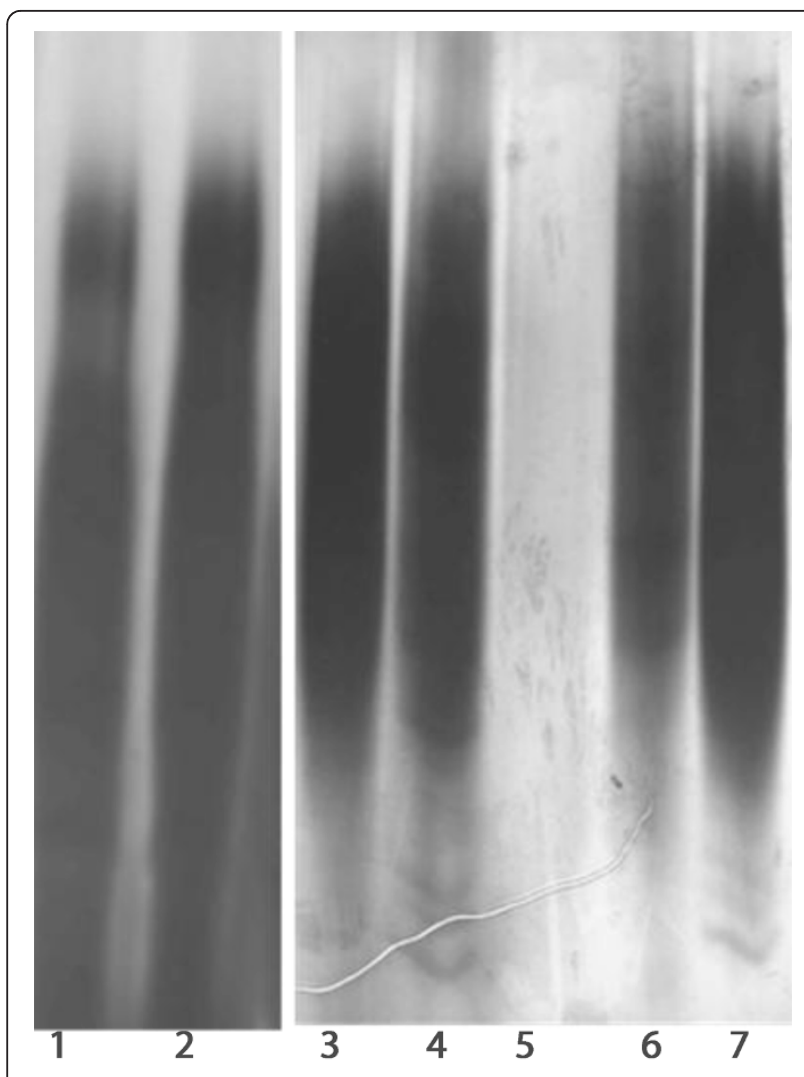

Figure 1 Electrophoretic profiles of semi-purified Cetavlon precipitates and biofilm. Bacteria were grown anaerobically on plates or to late stationary phase, Cetavlon added, and precipitates extracted, as described in Methods. Each extract was loaded onto 25\% polyacrylamide gels, followed by electrophoresis and staining with Alcian blue and silver. Lanes: 1 and 2, $20 \mu \mathrm{g}$ and $30 \mu \mathrm{g}$ of EPS extracted under growth conditions favorable to biofilm formation; 3 and 4, $20 \mu \mathrm{g}$ and $30 \mu \mathrm{g}$ of EPS extracted from cells grown to late stationary phase in broth, respectively; 5, buffer alone; 6 and 7, $20 \mu \mathrm{g}$ and $30 \mu \mathrm{g}$ of EPS extracted from cells grown anaerobically on plates, respectively.

\section{Effect of growth conditions on $\mathrm{H}$. somni exopolysaccharide production}

EPS production by strain 2336 appeared to be enhanced under stress or growth conditions that did not favor rapid or abundant growth. Therefore, to determine the relative amount of EPS produced per cell, the purified EPS content (dry weight) was determined in relation to the total amount of protein in the sample (Table 1). EPS production appeared to be upregulated in late stationary phase, relative to exponential phase growth at $37^{\circ} \mathrm{C}$. In addition, the amount of EPS/cellular protein was further enhanced when the bacteria were grown to the same density at early stationary phase under anaerobic and high salt conditions, but not at $42^{\circ} \mathrm{C}$.

\section{H. somni exopolysaccharide production}

As mentioned above, changing the environmental conditions to enhance $H$. somni EPS production, such as anaerobic conditions, often resulted in poor bacterial growth, making it difficult to purify large amounts of EPS. Although very little EPS was produced in broth during log phase, more EPS was produced after the bacteria reached late stationary phase. Therefore, the bacteria were grown in CTT for 48-72 $\mathrm{h}$ prior to harvesting the bacteria, enabling the EPS to be purified from the culture supernatant (Figure 1).

Larger quantities of EPS could be isolated by incubating the bacteria in $1 \mathrm{~L}$ of TTT in a $1 \mathrm{~L}$ bottle incubated at $37^{\circ} \mathrm{C}$ and rotated slowly at $70 \mathrm{rpm}$. After about $24 \mathrm{~h}$ incubation the medium was uniformly turbid with planktonic bacteria, but after 48-72 $\mathrm{h}$ incubation a large biofilm-like mass became established on the bottom of the flask. The top $900 \mathrm{ml}$ of clear medium was removed and the EPS was purified from the sediment.

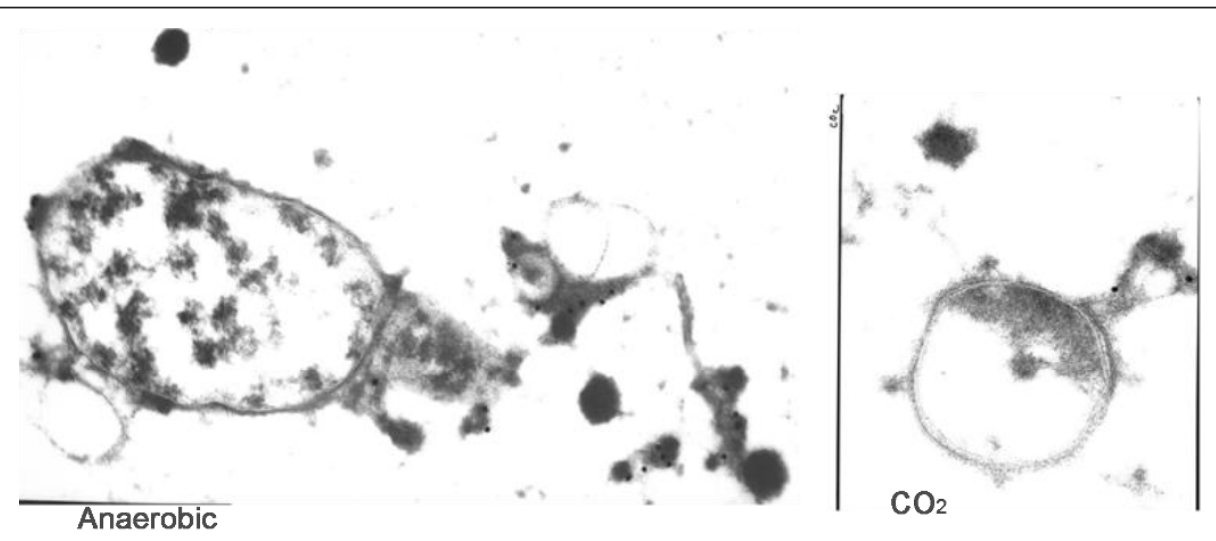

Figure 2 Immuno-transmission electron microscopy. Affinity-purified IgG was prepared from antiserum to isolated EPS made in rabbits, and incubated with whole cells that were gently scraped off plates, followed by Protein-A gold particles. The dark particles binding to the extracellular matrix (arrows) are Protein A-gold particles binding to immunoglobulins. Note that none of the Protein A-gold particles bound to the cell membrane, but were bound to extracellular material shed from the cell. More of this extracellular material was present when cells were grown anaerobically (left) than when cells were grown in $\mathrm{CO}_{2}$ (right). 
Table 1 H.somni EPS production under various growth conditions in relation to cellular protein content

\begin{tabular}{ll}
\hline Growth Conditions & $\begin{array}{l}\text { Relative Amount of EPS } \\
\text { (mg EPS/mg protein) }\end{array}$ \\
\hline $37^{\circ} \mathrm{C}$ (stationary phase) & 50.7 \\
$42^{\circ} \mathrm{C}$ (log phase) & 25.5 \\
$37^{\circ} \mathrm{C}$ (anaerobic growth) & 69.2 \\
$37^{\circ} \mathrm{C}$ (supplementation with $2 \% \mathrm{NaCl}$ ) & 95.1 \\
\hline
\end{tabular}

\section{Structural analysis of the exopolysaccharide}

Chemical analyses carried out by GLC-MS of the acetylated $O$-methyl glycoside and $O$-oct-2-yl glycoside derivatives yielded two monosaccharides, both in $\mathrm{D}$ configuration: mannose and traces of galactose. Methylation analysis showed the presence of derivatives of terminal Gal $p$, terminal Manp, 2-substituted Man $p$, 3substituted Manp, 6-substituted Manp, and 2,6-substituted Man $p$. On the basis of chemical data it could be hypothesised that the structure consisted of a mannan backbone to which other mannose (and some galactose) branching residues were attached. The ${ }^{1} \mathrm{H}$-NMR and ${ }^{13} \mathrm{C}$ NMR spectra appeared rather complex (Figure 3).

Chemical shifts were assigned utilizing DQF-COSY, TOCSY, ROESY, HSQC, and HMBC experiments (Table 2). Anomeric configurations were assigned on the basis of the chemical shifts of the ${ }^{3} \mathrm{~J}_{\mathrm{H}-1, \mathrm{H}-2}$ values, which were determined from the DQF-COSY experiment, and from the shifts of ${ }^{1} J_{\mathrm{C}-1, \mathrm{H}-1}$ values derived from a coupled ${ }^{1} \mathrm{H},{ }^{13} \mathrm{C}$-HSQC. Based on the TOCSY spectrum from the $\mathrm{H}-2$ proton signal for all the spin systems, it was possible to assign all of the resonances, and from these, all the ${ }^{13} \mathrm{C}$ resonances from the HSQC spectrum.

In the low field anomeric region several signals were present, all identifiable as mannose spin systems (low ${ }^{3} J_{\mathrm{H}-1, \mathrm{H}-2}$ and ${ }^{3} \mathrm{~J}_{\mathrm{H}-2, \mathrm{H}-3}$ values) experiencing a different magnetic environment. At $5.28 \mathrm{ppm}$ a cluster of signals were present, all indicative of 2 -substituted mannose residues. In fact, ${ }^{13} \mathrm{C}$ resonance assignments showed the downfield displacement of a $\mathrm{C}-2$ resonance for the spin system, evidently due to glycosylation. Furthermore, at $5.16 \mathrm{ppm}$ a cluster of signals indicated that a 3 -substituted mannose was present, as attested by the downfield shift of C-3 resonance at $79.1 \mathrm{ppm}$. At 5.13 and 5.10 ppm two very similar spin systems were found. Both residues possessed $\mathrm{C}-2$ and $\mathrm{C}-6$ chemical shifts at low fields owing to glycosylation, and were therefore identified as two distinct clusters of 2,6-di-subtituted mannose residues that experienced a slightly different magnetic environment. Likewise, at 5.03 and $5.04 \mathrm{ppm}$, it was possible to identify two non-substituted mannose residues, as inferred by their ${ }^{1} \mathrm{H}$ and ${ }^{13} \mathrm{C}$ resonances. The last mannose residue was present at $4.889 \mathrm{ppm}$ and was representative of a 6 -substituted mannose, given the downfield shift value of its C-6 resonance. At higher fields (4.52 $\mathrm{ppm})$ another anomeric proton signal was
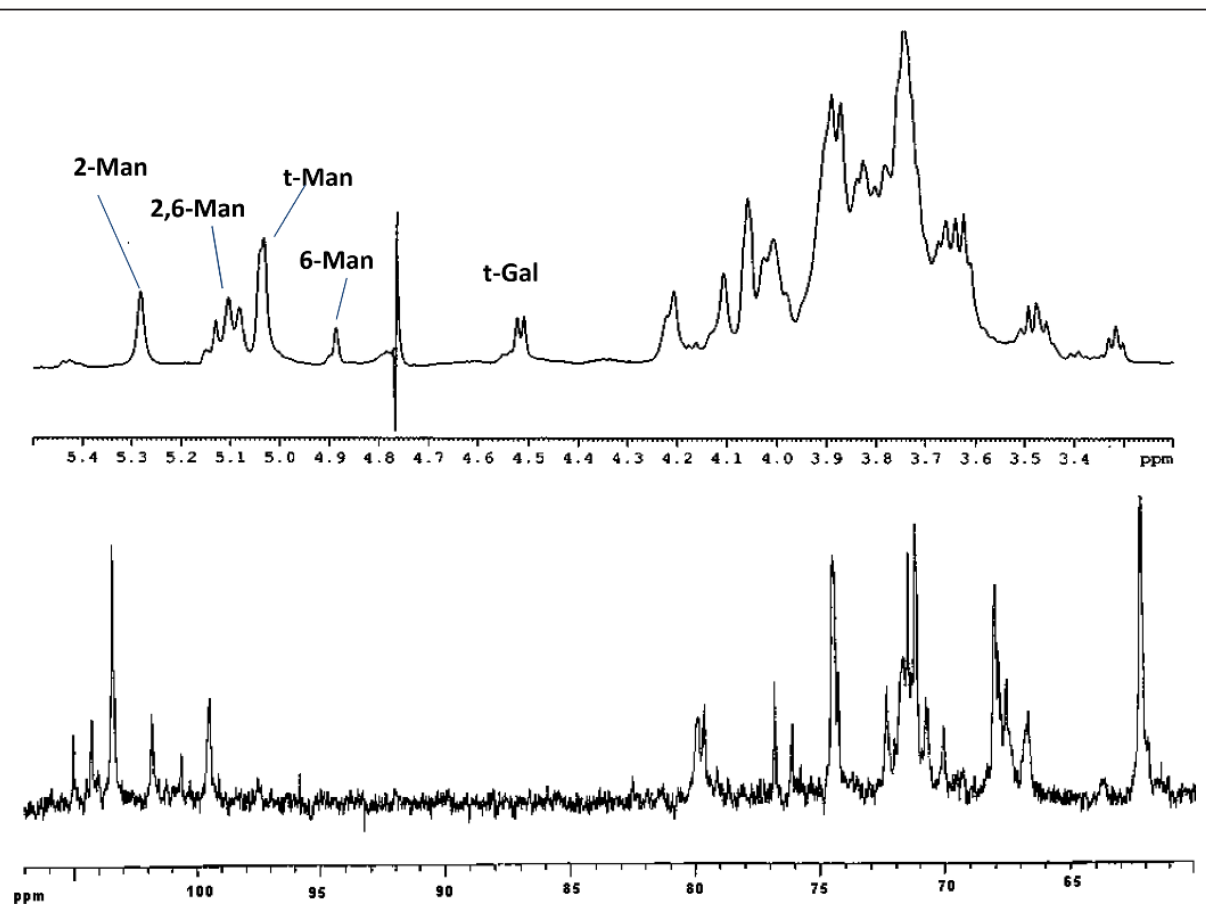

Figure 3 The ${ }^{1} \mathrm{H}$ - (A) and the ${ }^{13} \mathrm{C}$-NMR spectra from the purified EPS of $\boldsymbol{H}$. somni $\mathbf{2 3 3 6}$. The spectrum was recorded in $\mathrm{D}_{2} \mathrm{O}$ at $25^{\circ} \mathrm{C}$, relative to the HOD signal at $4.78 \mathrm{ppm}$. 
Table $2{ }^{1} \mathrm{H}$ and ${ }^{13} \mathrm{C}$ NMR data of the galactomannan fraction from Histophilus somni 2336

\begin{tabular}{lllllll}
\hline Residue & $\mathbf{1}$ & $\mathbf{2}$ & $\mathbf{3}$ & $\mathbf{4}$ & $\mathbf{5}$ & $\mathbf{6}$ \\
\hline 2-Manp & 5.28 & 4.10 & 3.91 & 3.72 & 3.71 & $3.87,3.72$ \\
& 101.2 & 79.3 & 71.0 & 67.4 & 75.4 & 61.8 \\
3-Manp & 5.16 & 4.21 & 3.88 & 3.65 & 3.76 & $3.89,3.74$ \\
& 103.2 & 71.1 & 79.1 & 66.0 & 75.3 & 62.0 \\
2,6-Manp & 5.13 & 4.22 & 3.87 & 3.60 & 3.76 & $3.88,3.73$ \\
& 99.2 & 79.1 & 71.1 & 66.1 & 74.6 & 68.0 \\
2,6-Manp & 5.10 & 4.03 & 3.93 & 3.69 & 3.80 & $4.00,3.70$ \\
& 99.2 & 79.6 & 71.5 & 67.8 & 74.6 & 67.6 \\
t-Manp & 5.03 & 4.06 & 3.86 & 3.66 & 3.75 & $3.89,3.71$ \\
& 103.2 & 71.0 & 71.2 & 67.5 & 76.4 & 62.1 \\
t-Manp & 5.04 & 4.20 & 3.93 & 3.62 & 3.86 & $3.89,3.71$ \\
& 103.2 & 70.1 & 70.7 & 67.9 & 76.4 & 62.1 \\
6-Manp & 4.89 & 3.98 & 3.82 & 3.71 & 3.88 & $3.91,3.73$ \\
& 100.6 & 70.6 & 71.0 & 67.3 & 74.8 & 66.5 \\
t-Galp & 4.52 & 3.32 & 3.48 & 3.87 & 3.84 & $3.84,4.21$ \\
\hline
\end{tabular}

present, which was attributable to the galactopyranose residue present in its $\beta$-anomeric configuration $\left({ }^{3} J_{\mathrm{H}-1, \mathrm{H}-}\right.$ ${ }_{2}=8.1 \mathrm{~Hz}$ ). Analysis of the TOCSY spectrum made it possible to determine the $\mathrm{H}-1$ to $\mathrm{H}-4$ resonances. In contrast, the $\mathrm{H}-5$ resonance, as in all galacto-configured systems, was only visible by NOESY owing to its low coupling constant with $\mathrm{H}-4$, which impaired any transfer of magnetization. The chemical shifts of carbon signals of this latter spin system were taken from HSQC, and indicated there was no glycosylation shift, suggesting the presence of an unsubstituted $\beta$-galactopyranose residue.

On the basis of the above chemical and NMR data, and in accordance with reported data [48], it was likely that the EPS was an $\alpha-(1 \rightarrow 6)$-linked, highly branched, comb-like mannopyranan polysaccharide structure with mannopyranose units branched at C-2 with 2-substituted mannose residues. In order to confirm this structural hypothesis, we carried out an enzymatic hydrolysis on $10 \mathrm{mg}$ of the EPS using an exo-mannosidase that is able to cleave the branching mannose residues starting from the non-reducing ends. As expected, after purification by gel filtration chromatography, two products were identified. The lower molecular size fraction was mannose $(6 \mathrm{mg})$. The polysaccharide fraction that eluted in the void volume ( $3 \mathrm{mg}$ ) was analysed by NMR spectroscopy, and although still present as part of a heterogeneous polymer, this fraction consisted of only one major residue. The comparison of proton anomeric signal intensities between the polymer and the mannosidase-degraded product showed a remarkable increase in the signal at $\delta 4.89$ (6-substituted mannose) with respect to all the other signals (Figure 4). However, it was not possible to observe the galactose signal in this polymer, likely because the amount of galactose in the entire EPS

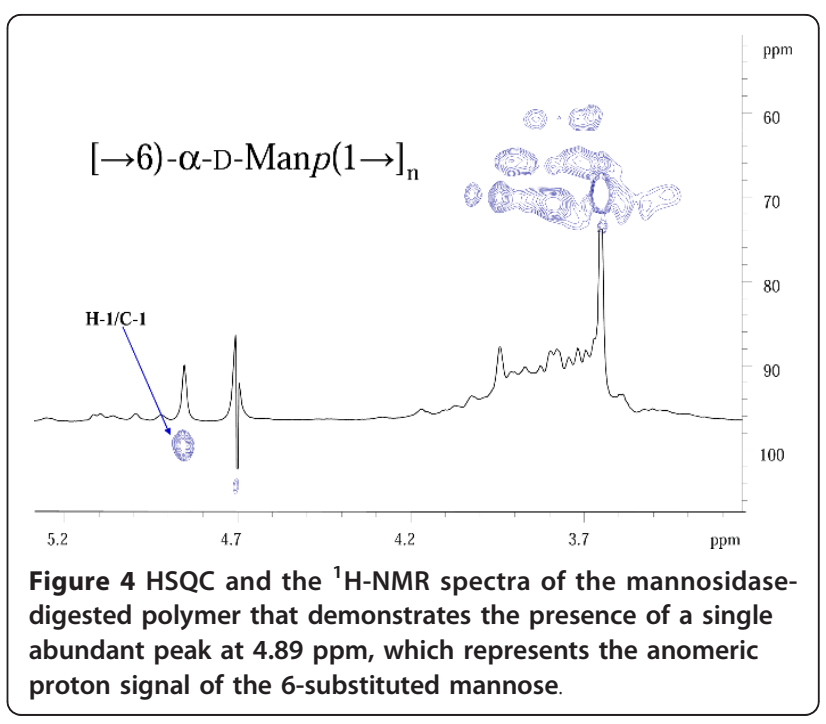

was very low and in the presence of the predominant mannose, disappeared due to background noise. The methylation analysis was in good agreement with this observation, and showed a substantially higher content of 6-substitued mannose. Following the exo-mannosidase hydrolyses of the terminal mannose units, it was confirmed that 6 -substituted mannose was a constituent of the mannan backbone and that 2- substituted and 3substituted mannose were present in the oligosaccharide arms.

After establishing the nature of the backbone, an acetolysis reaction was used to determine the identity and length of the branches. This reaction selectively cleaves the $(1 \rightarrow 6)$-glycosidic linkages furnishing, in this case, the intact lateral chains of the polymer with a reducing mannose that was originally present as the 6 -substituted residue in the backbone. The crude reaction mixture was separated by TSK-40 gel-filtration chromatography, and yielded four fractions (1-4) that were all subjected to a combination of chemical and spectroscopic analyses.

Fraction 1 was established to be a mannose-reducing tetrasaccharide and contained a slight amount of a tetrasaccharide, in which galactose replaced the non reducing mannose end as follows:

$$
\begin{aligned}
& \alpha-\mathrm{D}-\operatorname{Man} p-(1 \rightarrow 3)-\alpha-\mathrm{D}-\operatorname{Man} p-(1 \rightarrow 2)-\alpha-\mathrm{D}-\operatorname{Man} p-(1 \rightarrow 2)-\mathrm{D}-\mathrm{Man} p-r e d . \\
& \beta-\mathrm{D}-\mathrm{Gal} p-(1 \rightarrow 3)-\alpha-\mathrm{D}-\operatorname{Man} p-(1 \rightarrow 2)-\alpha-\mathrm{D}-\operatorname{Man} p-(1 \rightarrow 2)-\mathrm{D}-\mathrm{Man}-r e d
\end{aligned}
$$

Fraction 2 was found to be a trisaccharide: $\alpha-D-$ $\operatorname{Man} p-(1 \rightarrow 2)-\alpha-\mathrm{D}-\operatorname{Man} p-(1 \rightarrow 2)-\mathrm{D}-M a n-r e d$, fraction 3 consisted of the disaccharide $\alpha$-D-Man $p-(1 \rightarrow 2)$-D-Man$r e d$, and fraction 4 was only composed of reducing mannose. Thus, the acetolysis showed that only three kinds of oligosaccharides were present, which were attached 
to the main polymer backbone, and that these branches were all attached to O-2 of a 2,6-disubstituted mannose. Moreover, the galactose residue, when present, was only located at the non-reducing end of a tetrasaccharide. Thus, from both selective degradation reactions, it could be concluded that the galacto-mannan polymer is an intricate structure consisting of a 6-substituted mannan backbone with small branching chains (one to three units) of Man $p$ residues. Furthermore, the 3-substituted mannose is only present in the trisaccharide lateral chain. The overall structure of this complex EPS is shown in Figure 5.

When 2336 and 129Pt were grown with and without Neu5Ac added to the culture medium, only traces of Neu5Ac were present in the purified EPS of 129Pt without Neu5Ac (Figure 6, left panel), with Neu5Ac (Figure 6, right panel), or in 2336 grown without Neu5Ac (Figure 7, left panels). However, a significantly larger quantity of Neu5Ac was present in the EPS of 2336 grown with Neu5Ac (Figure 7, right panels). Furthermore, the EPS also contained two additional aminosugars: $N$-acetylglucosamine and $N$-acetylgalactosamine.

\section{Association of the exopolysaccharide with biofilm}

The presence of EPS in the $H$. somni biofilm was examined by cryo-ITEM following incubation of the fixed samples with antiserum to EPS and Protein-A gold particles. The Protein-A gold particles bound to the bacterial surface and in spaces between the cells, which appeared to be the residual biofilm matrix. However, no gold particles were seen in the control sample incubated without antiserum (Figure 8).

Mannose is not present in the H. somni LOS, but is the predominant component of the EPS. Therefore, a fluorescein isothionate-labeled, mannose-specific lectin (Morniga $M$ [black mulberry]) was incubated with $H$. somni biofilms. This lectin bound to the matrix material between the cells of the biofilm of 2336 (Figure 9), indicating that the EPS was a major component of the $H$. somni biofilm. Analysis of the biofilm embedded in OCT resin with the sialic acid-reactive lectins (MAA

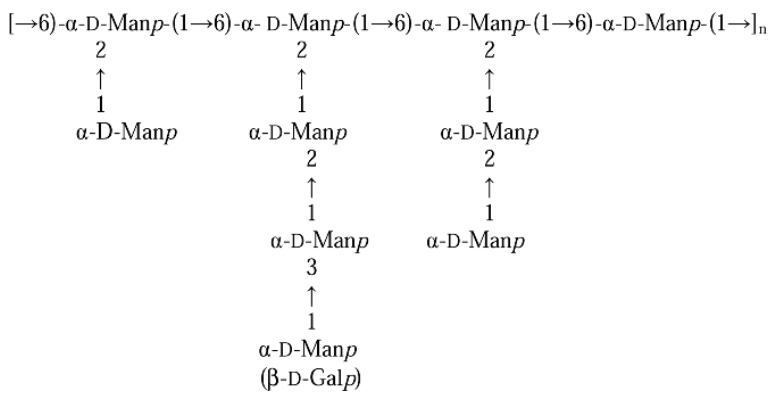

Figure 5 Proposed structure of the EPS of H. somni 2336
[Maackia amurensis], WGA [Wheat Germ agglutinin], HHA [Amaryllis], and SBA [soybean] further supported that Neu5Ac was also a component of the biofilm of 2336 (data not shown). SEM examination showed that the addition of Neu5Ac to chemically defined medium increased biofilm production by 2336, whereas biofilm formation by $129 \mathrm{Pt}$ was unchanged (Figure 10). Although the LOS of 2336 was sialylated when grown in the presence of Neu5Ac, there were no differences in LOS structure or sialylation levels when 2336 was grown as a biofilm, as planktonic cells, or on blood agar plates (additional file 1, Table S1). In the absence of supplemental Neu5Ac, only LOS from 2336 grown on blood agar plates was sialylated, presumably due to the presence of Neu5Ac in the fresh blood. As previously reported [12], the LOS of $129 \mathrm{Pt}$ grown under any of the above conditions was not sialylated.

\section{Putative polysaccharide locus in H. somni 2336}

To understand the genetic basis of EPS biosynthesis in $H$. somni, we sought to identify a locus of genes that could encode for enzymes involved in the synthesis and transport of a polysaccharide other than LOS. A homo$\log$ of $\operatorname{manB}$, which encodes for phosphomannomutase, was identified in the genomes of 2336 and 129Pt [2,25]. Phosphomannomutase is responsible for conversion of mannose-6-phosphate to mannose-1-phosphate. Furthermore, $\operatorname{manB}$ is flanked by gall , a glucose pyrophosphorylase, and $c s r A$, a putative carbon storage regulator (Table 3 and additional file 2, Figure S1). Genome annotation also identified the presence of a $\sim 19 \mathrm{~kb}$ region that contains a cluster of genes predicted to encode for glycosyltransferases, transport proteins, and other proteins involved in polysaccharide biosynthesis (Table 3 and additional file 2, Figure S1). The G+C content $(36 \%)$ of this locus was similar to that of $H$. somni genomes $(37 \%)[2,25]$.

\section{Differential gene expression in biofilm and planktonic cells}

Among the 19 genes in the two loci described above, fourteen genes were upregulated when H. somni 2336 was grown under conditions favorable to biofilm formation, compared to planktonic-grown cells (Figure 11). The greatest level of induction (8-fold) when the cells were in biofilm phase occurred for $r b s 2 a$, which had the greatest sequence similarity to a gene encoding for an ATP-binding constituent of the ribose ATP-binding cassette protein $(\mathrm{ABC})$ transporter. Furthermore, $r b s 2 b$ and $r b s 2 c$, which are similar to genes encoding for a periplasmic substrate-binding protein and a transmembrane constituent of the ribose $\mathrm{ABC}$ transporter, respectively, were also upregulated in biofilm phase cells (Table 3 ). H. somni galU, which is essential for galactose 


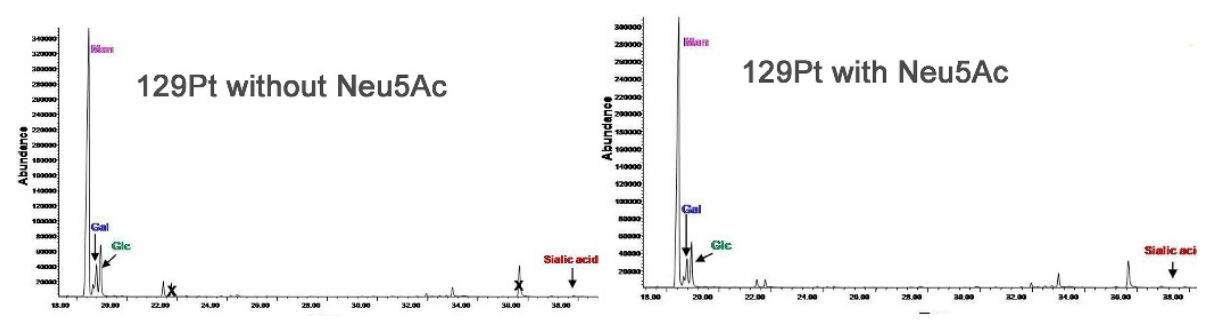

Figure 6 Chromatogram GC-MS of H. somni 129 pt grown without Neu5Ac (left) and with Neu5Ac (right).

utilization and synthesis of a variety of carbohydrates, was upregulated 7-fold when grown in the biofilm phase compared to planktonic growth, supporting the potential role of this gene for EPS biosynthesis (Figure 11). The putative functions of other genes, which were upregulated 2-5 fold (Figure 11) are described in Table 3. In contrast to the large number of genes in this locus that were upregulated when 2336 was grown as a biofilm, only five genes in this locus were upregulated, and then only 1-2 fold, when $129 \mathrm{Pt}$ was grown as a biofilm (Figure 11). These results supported that these loci contributed to EPS production, and were consistent with previous results that the biofilm is thicker and larger in 2336 compared to $129 \mathrm{Pt}$ [29]. In addition to the genes in the putative EPS loci, expression of siaB, which encodes for alpha-2,3-sialyltransferase, was upregulated 15-fold when 2336 was grown as a biofilm compared to planktonic cells (data not shown).

\section{Discussion}

It is now established that $H$. somni makes an excellent biofilm in vitro and in vivo $[29,49]$, but the nature of the biofilm matrix has not been characterized. The biofilm matrix of most bacterial cells contains polysaccharide that is upregulated under conditions that favor biofilm growth, such as the EPS in the biofilm of Pseudomonas aeruginosa [50,51]. Miller et al. [28] reported the presence of a polysaccharide in the supernatant of $H$. somni colonies washed off culture plates. However, the nature and composition of this polysaccharide was not reported, and it was not differentiated from LOS.

Anaerobiosis is also commonly associated with host infections and the substratum of biofilms [52]. Therefore, we sought to determine if the phenotype of $H$. somni changed when the bacteria were grown under anaerobic conditions. Although there was no substantial change in the LOS profile or outer membrane protein profile, which occurs when $N$. gonorrhoeae is grown anaerobically [53], a high molecular size polysaccharide was produced by $H$. somni under anaerobic growth conditions. Furthermore, production of this polysaccharide was enhanced under other stress conditions, such as stationary phase, increased salt content, and conditions that favor biofilm formation. Therefore, this polysaccharide is likely to be produced in the host, where the competition for nutrients and the host response
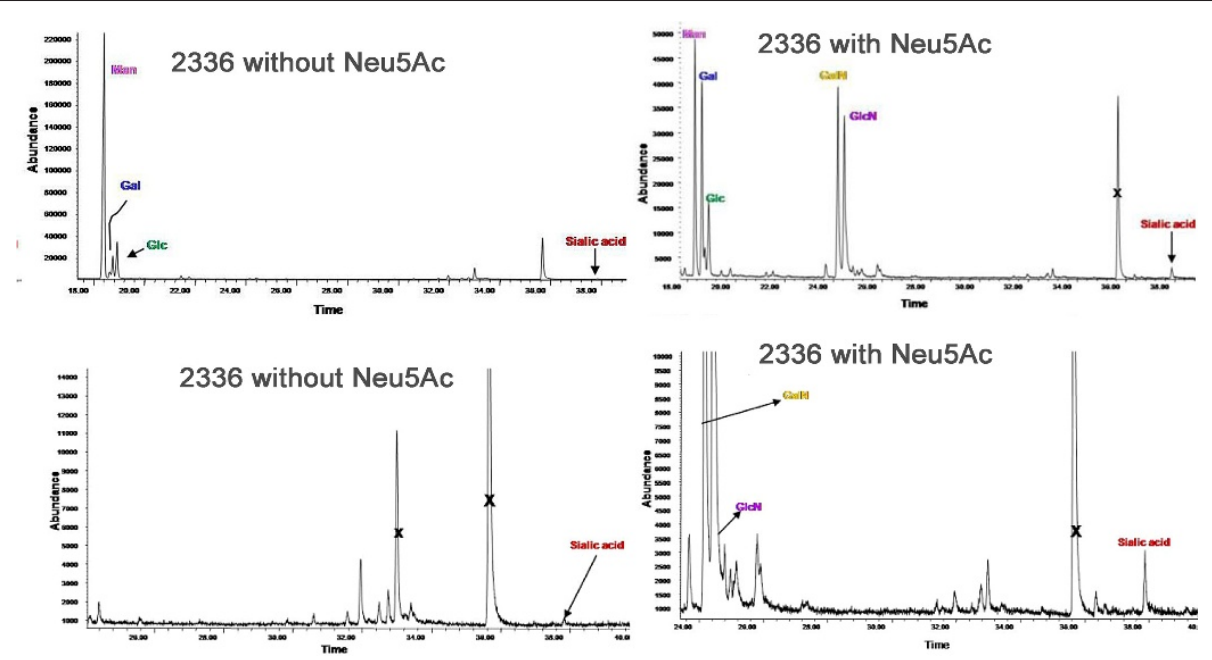

Figure 7 Chromatogram GC-MS of $H$. somni 2336 grown without Neu5Ac (top left) and with Neu5Ac (top right), and chromatogram expansion GC-MS of 2336 grown without Neu5Ac (bottom left) and with Neu5Ac (bottom right). 


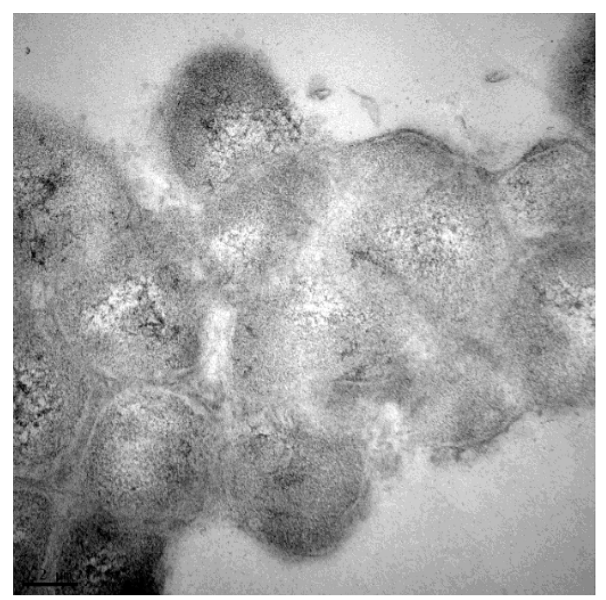

Control

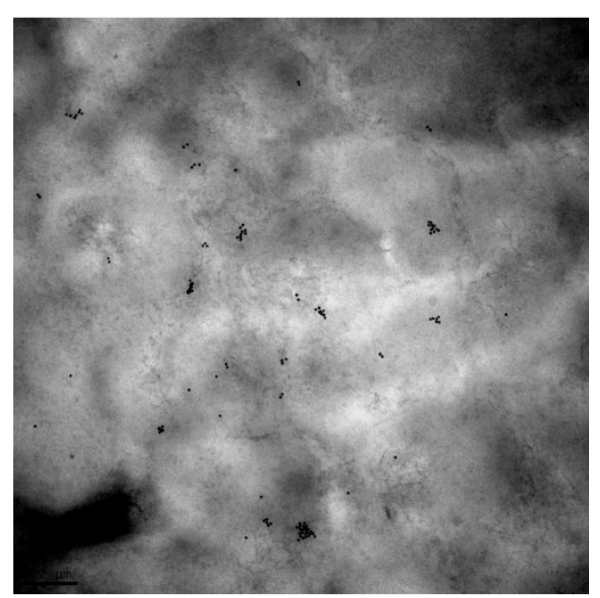

Antibody to EPS

Figure 8 Immuno-transmission electron micrographs of the OCT cryosection of an H. somni biofilm. H. somni was grown as a biofilm on glass slides and embedded in OCT resin to maintain the integrity of the biofilm prior to incubation with antiserum. Left, control OCT cryosection of biofilm incubated without specific antiserum, but with anti-rabbit conjugated gold particles; no labeling with the gold particles occurred; Right, OCT cryosection of a biofilm incubated with rabbit antibodies to EPS, followed by anti-rabbit conjugated gold particles. The black dots are gold particles around the bacterial cells and in the residual biofilm matrix.

continually stresses bacterial cells. The polysaccharide did not appear to be attached to the cell surface, and was therefore consistent with it being an EPS rather than a capsule. The failure to previously characterize this EPS was due to the fact that little, if any, of this material was produced during log phase (planktonic growth) in broth.
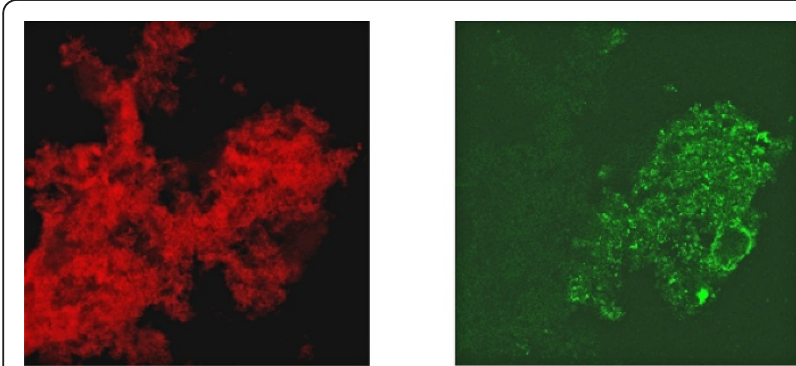

Pro-3

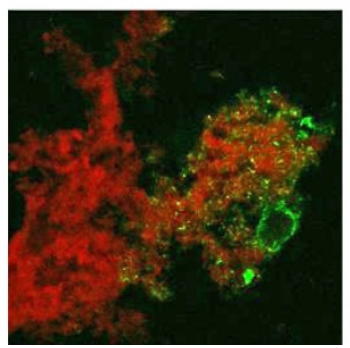

MNA-FITC

Merged

Figure $9 \mathrm{H}$. somni biofilm labeled with Moringa M lectin. $\mathrm{H}$. somni was grown as a biofilm on cover slips and stained with TOPRO-3 to label the bacterial cells (top left), MNA (specific for $\alpha$ mannose)-FITC to label mannose (top right), and were merged (bottom center) to demonstrate the presence of mannose within the bacterial biofilm. Mannose is present in the H. somni EPS, but not in the LOS.
Purification of the EPS was initially difficult due to poor growth of the bacteria under anaerobic conditions and the relatively small amount of EPS made even in stationary phase broth cultures. The greatest amount of EPS:cell mass ratio was clearly produced under conditions that favored biofilm formation. The chemical structure of the EPS from 2336 was that of a complex, branched, galacto-mannan polymer consisting of a 6 substituted mannose framework that branched at C-2 with occasional galactose residues at the non-reducing end of the tetrasaccharide branch. This structure is remarkably similar to that of yeast mannan [54]. Attempts to purify a mannan-containing polysaccharide from the growth medium alone, including supplemented BHI, Terrific broth, and Columbia broth, were unsuccessful, confirming that this material was not derived from yeast extract in the medium. Antibodies to the EPS and the lectin Morniga M (MNA; specific for $\alpha$ mannose, which is only present in the EPS) bound to and between $H$. somni cells grown in a biofilm, indicating the EPS was part of the biofilm matrix.

Due to the presence of terminal galactose residues in the EPS, and that $H$. somni can sialylate the terminal galactose residues of its LOS, we sought to determine if the EPS could also be sialylated. GC-MS confirmed that when 2336 was grown in the presence of Neu5Ac the EPS was sialylated, but the EPS of 129Pt was not. The lack of sialylation of 129Pt EPS was expected as this strain lacks the sialyltransferases and Neu5Ac-synthetase required to attach Neu5Ac to galactose residues [25]. However, there was no difference in the sialylation of LOS glycoforms in planktonic, plate-grown, or biofilm- 

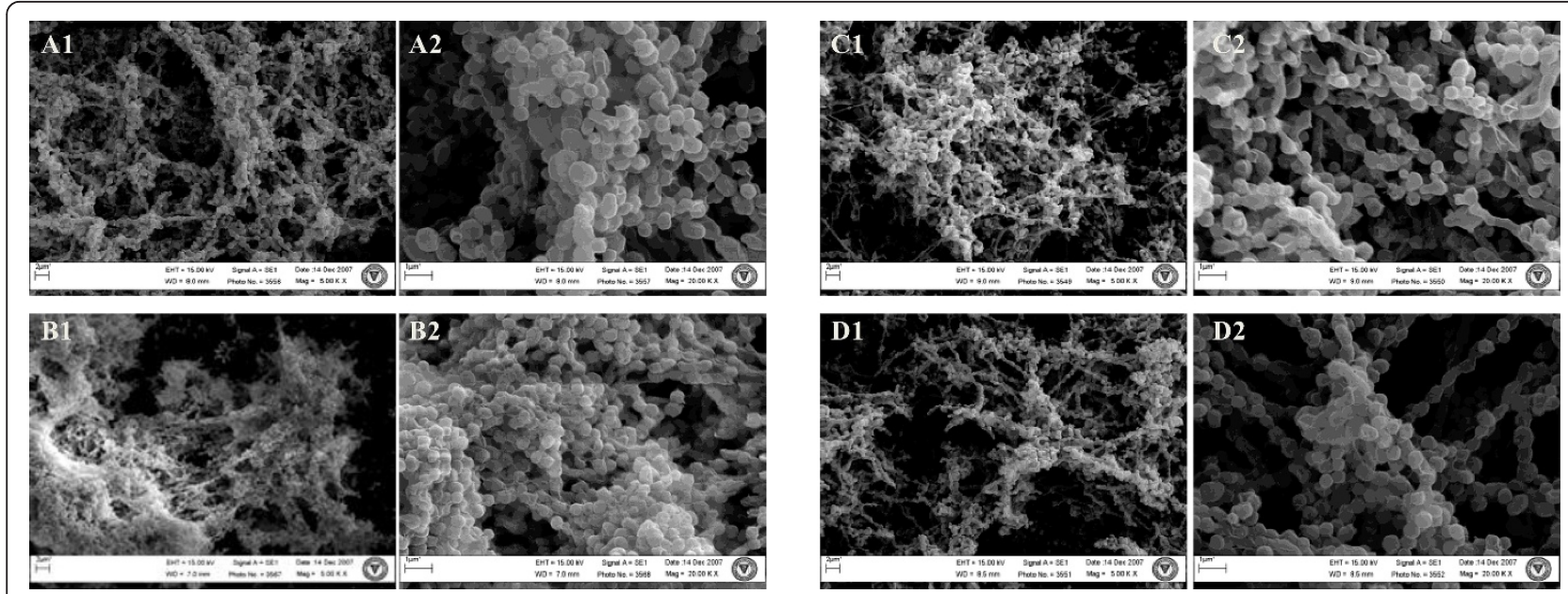

Figure 10 SEM image of biofilm formation by H. somni 2336 and 129Pt. A1-A2, biofilm formation by 2336; B1- B2, enhanced biofilm formation by 2336 grown in the presence of Neu5Ac (50 $\mathrm{\mu g} / \mathrm{ml})$ in chemically defined medium; C1- C2, biofilm formation by 129Pt; D1- D2, biofilm formation by 129Pt grown in the presence of Neu5Ac in defined medium. There is no significant change in the density of the biofilm of 129Pt grown in the presence of Neu5Ac.

grown cells, suggesting that Neu5Ac promoted biofilm formation in H. somni 2336 through sialylation of the EPS.

In $H$. somni the presence of Neu5Ac on the LOS reduces antibody binding and promotes serum resistance $[12,55]$. Neu5Ac is also a normal component of host cells, thereby mimicking human oligosaccharides [7]. Neu5Ac on the LOS also binds to complement factor $\mathrm{H}$ [56], and protects the bacteria from complementmediated killing [57]. In nontypable $H$. influenzae (NTHI), which does not produce a known EPS, sialylation of the LOS promotes biofilm formation [58]. Neu5Ac is a terminal sugar of the NTHI biofilm matrix [59] and is required for biofilm formation in the otitis media Chinchilla model [60]. Inactivation of siaB (CMPNeu5Ac synthetase) prevents addition of Neu5Ac onto the LOS and attenuates the mutant in the otitis media model, in which biofilm is a predominant component $[60,61]$.

A BLAST search of the genome sequences of 2336 and 129Pt identified putative genes in two regions that could encode for proteins responsible for EPS synthesis [[25], Siddaramappa S CJ, Duncan AJ, Gillaspy AF, Carson M, Gipson J, Gipson M, Orvis J, Zaitshik J, Barnes G, Brettin TS, Bruce D, Chertkov O, Detter JC, Han CS, Tapia R, Thompson LS, Dyer DW, Inzana TJ: Genome sequence of Histophilus somni strain 2336 from bovine pneumonia and comparison to commensal strain $129 \mathrm{Pt}$ reveals extensive horizontal gene transfer and evolution of pathogenesis. Submitted]. One locus contained 16 genes with similarity to genes responsible for carbohydrate assembly, transport, and polysaccharide synthesis. Another region contained genes with high homology to
galU, $\operatorname{man} B$, and $c s r$, which could be involved in the synthesis of any polymer containing galactose and mannose. The putative functions of the products of some of these genes resemble those of the $P$. aeruginosa $p s l$ (polysaccharide synthesis locus), which consists of a group of 15 genes encoding for enzymes responsible for synthesis of the mannose- and galactose-rich biofilmassociated EPS [50,62,63]. Attempts to mutate any of these $H$. somni genes by allelic replacement using pGEM3Z, as previously described [10], or other $H$. somni suicide vectors were unsuccessful. Therefore, qRT-PCR was used to determine if enhanced expression of the EPS, which occurs during biofilm formation, correlated with upregulation of the putative EPS locus. More than two-thirds of the genes in this locus were significantly upregulated when the bacteria were grown under conditions favorable to biofilm formation (and EPS production), compared to planktonic growth. Some of the putative genes with the largest induction in expression were those encoding for periplasmic substrate-binding proteins and transmembrane constituents of the ribose $A B C$ transporter. This family of $A B C$ transporters represents domain II of the carbohydrate uptake proteins that transport only monosaccharides. In E. coli, mutations in any of these genes ( $r b s a, r b s b, r b s c)$ eliminates transport of ribose, indicating that these components form a transport system that is responsible for high-affinity ribose transport [64]. The gene galu, which encodes for glucose-1-phosphate uridylyltransferase, was also highly upregulated and is responsible for catalyzing the reversible production of UDP-glucose. The gene galU plays a pivotal role in the synthesis of the carbohydrate moieties of glycolipids, glycoproteins, and 
Table 3 Putative EPS genes in H.somni 2336 and 129Pt with proposed roles in polysaccharide synthesis

\begin{tabular}{|c|c|c|c|c|}
\hline Gene & $\begin{array}{l}\text { ORF } \\
\text { (HSM-H. somni } 2336 \\
\text { and HS- H. somni 129Pt) }\end{array}$ & Protein annotation & $\begin{array}{l}\text { No. of amino acids, } \\
\text { predicted mass }(\mathrm{kDa})\end{array}$ & $\%$ Similarity to another protein \\
\hline galu & $\begin{array}{l}\text { HSM_1063 } \\
\text { HS_1117 }\end{array}$ & $\begin{array}{l}\text { UTP-glucose-1-phosphate } \\
\text { uridylyltransferase }\end{array}$ & $295,32.2$ & $\begin{array}{l}\text { 70, to glucose-1-phosphate uridylyltransferase, } \\
\text { galU (E. coli) }\end{array}$ \\
\hline $\operatorname{man} B$ & $\begin{array}{l}\text { HSM_1062 } \\
\text { HS_1118 }\end{array}$ & Phosphomannomutase & $454,50.3$ & 81, to phosphomannomutase, cpsG (E. coli) \\
\hline $\operatorname{csr} A$ & $\begin{array}{l}\text { HSM_1061 } \\
\text { HS_1119 }\end{array}$ & Carbon storage regulator & $60,6.75$ & $\begin{array}{l}\text { 89, to pleiotropic regulatory protein for carbon } \\
\text { source metabolism, csrA (E. coli) }\end{array}$ \\
\hline pldB & $\begin{array}{l}\text { HSM_1242 } \\
\text { HS_0775 }\end{array}$ & Lysophospholipase & $318,37.4$ & 49, to lysophospholipase L2, pldB (E. coli) \\
\hline$y b h A$ & $\begin{array}{l}\text { HSM_1241 } \\
\text { HS_0774 }\end{array}$ & $\begin{array}{l}\text { Haloacid dehalogenase-like } \\
\text { hydrolase }\end{array}$ & $273,30.8$ & $\begin{array}{l}60, \text { to phosphatase//phospho transferase, ybhA ( } E \text {. } \\
\text { coli) }\end{array}$ \\
\hline $\operatorname{araD}$ & $\begin{array}{l}\text { HSM_1240 } \\
\text { HS_0773 }\end{array}$ & $\begin{array}{l}\text { L-ribulose-5-phosphate 4- } \\
\text { epimerase }\end{array}$ & $231,25.8$ & $\begin{array}{l}\text { 82, to L-ribulose-5-phosphate 4-epimerase, yiaS ( } E \text {. } \\
\text { coli) }\end{array}$ \\
\hline$s g b U$ & $\begin{array}{l}\text { HSM_1239 } \\
\text { HS_0772 }\end{array}$ & $\begin{array}{l}\text { Putative L-xylulose-5-phosphate 3- } \\
\text { epimerase }\end{array}$ & $290,33.2$ & $\begin{array}{l}\text { 84, to L-xylulose 5-phosphate 3-epimerase, yiaQ (E. } \\
\text { coli) }\end{array}$ \\
\hline rmpA & $\begin{array}{l}\text { HSM_1238 } \\
\text { HS_0771 }\end{array}$ & $\begin{array}{l}\text { 3-keto-L-gulonate-6-phosphate } \\
\text { decarboxylase }\end{array}$ & $215,23.6$ & $\begin{array}{l}\text { 64, to 3-keto-L-gulonate 6-phosphate } \\
\text { decarboxylase, yiaQ (E. coli) }\end{array}$ \\
\hline$x y \mid B$ & $\begin{array}{l}\text { HSM_1237 } \\
\text { HS_0770 }\end{array}$ & L-xylulose kinase & $484,53.7$ & 75, to L-xylulose kinase, lyxK (E. coli) \\
\hline $\operatorname{rbsic}$ & $\begin{array}{l}\text { HSM_1236 } \\
\text { HS_0769 }\end{array}$ & Ribose $A B C$ transporter, permease & $342,32.9$ & 59, to D-ribose transporter subunit, rbsc (E. coli) \\
\hline $\operatorname{rbs} 1 \mathrm{~A}$ & $\begin{array}{l}\text { HSM_1235 } \\
\text { HS_0768 }\end{array}$ & $\begin{array}{l}\text { Ribose ABC transporter, ATPase } \\
\text { component }\end{array}$ & $496,56.1$ & $\begin{array}{l}\text { 60, to D-ribose transporter subunit, ATP-binding } \\
\text { component, rbsA (E. coli K12) }\end{array}$ \\
\hline $\operatorname{rbs} 1 B$ & $\begin{array}{l}\text { HSM_1234 } \\
\text { HS_0767 }\end{array}$ & $\begin{array}{l}\text { ABC-type sugar transport system, } \\
\text { periplasmic component }\end{array}$ & $312,31.0$ & $\begin{array}{l}\text { 56, to D-ribose transporter subunit, periplasmic } \\
\text { component (E. coli ) }\end{array}$ \\
\hline glss & $\begin{array}{l}\text { HSM_1233 } \\
\text { HS_0766 }\end{array}$ & Gluconolaconase & $295,32.6$ & $\begin{array}{l}\text { 46, to gluconolactonase, gnl } \\
\text { (Zymomonas mobilis) }\end{array}$ \\
\hline $\operatorname{rbs} 2 B$ & $\begin{array}{l}\text { HSM_1232 } \\
\text { HS_0765 }\end{array}$ & $\begin{array}{l}\text { ABC-type sugar-binding } \\
\text { periplasmic protein }\end{array}$ & $369,37.2$ & $\begin{array}{l}\text { 81, to hypothetical protein (Yersinia intermedia } \\
\text { ATCC 29909) }\end{array}$ \\
\hline $\operatorname{rbs} 2 \mathrm{C}$ & $\begin{array}{l}\text { HSM_1231 } \\
\text { HS_0764 }\end{array}$ & Ribose $A B C$ transporter, permease & $349,36.9$ & $\begin{array}{l}\text { 90, to inner-membrane translocator (Yersinia } \\
\text { intermedia ATCC 29909) }\end{array}$ \\
\hline $\operatorname{rbs} 2 \mathrm{~A}$ & $\begin{array}{l}\text { HSM_1230 } \\
\text { HS_0763 }\end{array}$ & $\begin{array}{l}\text { Ribose } A B C \text { transporter, ATPase } \\
\text { component }\end{array}$ & $505,55.8$ & $\begin{array}{l}\text { 81, to ABC transporter-related protein (Yersinia } \\
\text { intermedia ATCC 29909) }\end{array}$ \\
\hline$d c t P$ & $\begin{array}{l}\text { HSM_1229 } \\
\text { HS_0762 }\end{array}$ & $\begin{array}{l}\text { TRAP C4-dicarboxylate transport } \\
\text { system, periplasmic component }\end{array}$ & $328,33.4$ & $\begin{array}{l}\text { 52, to C4-dicarboxylate binding protein, } \\
\text { periplasmic component, dctP (Rhodobacter } \\
\text { capsulatus) }\end{array}$ \\
\hline dctM & $\begin{array}{l}\text { HSM_1228 } \\
\text { HS_0761 }\end{array}$ & $\begin{array}{l}\text { TRAP C4-dicarboxylate transport } \\
\text { system, permease component }\end{array}$ & $426,43.2$ & $\begin{array}{l}\text { 59, to C4-dicarboxylate -binding protein, permease } \\
\text { component, dctM (Rhodobacter capsulatus) }\end{array}$ \\
\hline dctQ & $\begin{array}{l}\text { HSM_1227 } \\
\text { HS_0760 }\end{array}$ & $\begin{array}{l}\text { Tripartite ATP-independent } \\
\text { periplasmic transporter }\end{array}$ & $160,17.8$ & $\begin{array}{l}\text { 40, to tripartite ATP-independent periplasmic } \\
\text { transporter, dctQ } \\
\text { (Rhodobacter capsulatus) }\end{array}$ \\
\hline
\end{tabular}

proteoglycans. gall is also essential for capsular polysaccharide biosynthesis in Streptococcus pneumoniae [65]. In H. influenzae, galu is an essential housekeeping gene that is important in generating sugar precursors needed for polysaccharide formation and LOS outer core synthesis [66]. The H. somni GalU in this locus is $70 \%$ similar to that of $H$. influenzae at the amino acid level. Of interest was that in 129Pt only 5 of the genes in these two loci were significantly upregulated when the bacteria were grown under conditions favorable to biofilm formation, which is much thinner and less substantial than that of 2336 [29], and much less EPS can be isolated from the biofilm of 129Pt (data not shown). Therefore, these experiments support the premise that these genes encode for proteins responsible for EPS biosynthesis.

It will be important to determine if all or most strains of $H$. somni produce an antigenically identical or similar EPS, and if antibodies to the EPS can be used to differentiate infected animals from healthy, colonized animals. Preliminary ELISA experiments with antibodies to the EPS indicated that most strains do produce this EPS. Serological studies with infected and healthy animals are in progress.

\section{Conclusions}

We describe the isolation and structure of an $H$. somni EPS. The EPS was upregulated under stress-like 

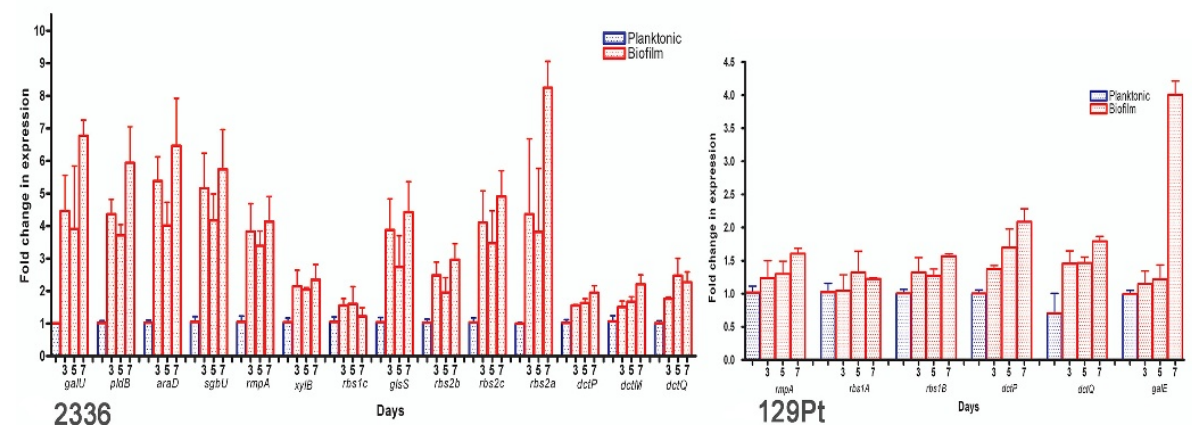

Figure 11 Genes predicted to contribute to EPS biosynthesis that were significantly $(P<0.05)$ upregulated during biofilm growth (red bars) relative to planktonic growth (blue bars). The bacteria were grown as biofilms or in broth (planktonic) and samples taken at 3, 5 and 7 days for analysis by qRT-PCR from H. somni 2336 (left) or 129Pt (right). Fourteen of 19 genes were significantly upregulated in 2336, whereas only 5 genes were upregulated (predominately at 7 days) in 129Pt. The data were expressed as the means and SDs of three independent experiments performed in triplicate.

conditions, and appeared to be a major component of the matrix of the H. somni biofilm. An attractive hypothesis is that formation of EPS and a biofilm is, in part, responsible for the capability of $H$. somni to persist in tissues and cause chronic infections. Since biofilm formation in the bovine host occurs during disease [49], it will be important to determine if compounds that inhibit EPS production will reduce biofilm formation in the host and hasten recovery. The putative genes responsible for EPS synthesis were also identified, which will lead to the development of mutants unable to synthesize EPS and determine the role of the EPS and biofilm in virulence. Furthermore, if EPS is produced primarily during the disease process, this antigen may prove useful in serological assays for diagnosis of $H$. somni infection.

\section{Additional material}

Additional file 1: Proposed composition of OdA LOS from $\mathrm{H}$. somni strains 2336 and $129 \mathrm{Pt}$ grown as a biofilm, as planktonic cells, or on blood agar plates by negative-ion-ES-MS. Data of the observed ions $(\mathrm{m} / \mathrm{z}$ ), observed and calculated molecular mass (in daltons), and proposed composition of O-deacylated lipooligosaccharides from $\mathrm{H}$. somni strains 2336, which can be sialylated, and 129Pt, which is cannot be sialylated, grown with and without sialic acid as a biofilm, planktonically, and on blood agar.

Additional file 2: Maps of $\mathrm{H}$. somni 2336 chromosomal loci containing genes proposed to encode for proteins involved in EPS biosynthesis. $\mathrm{A}$, an $\sim 19 \mathrm{~kb}$ region containing genes predicted to encode for glycosyltransferases and transport proteins; $B$, an $\sim 3 \mathrm{~kb}$ region that contains manB. For detailed analyses of the putative gene products see Table 3 .

\section{List of abbreviations}

EPS: exopolysaccharide; Neu5Ac: N-acetylneuraminic acid; GRT-PCR: quantitative real-time reverse transcription-polymerase chain reaction; LOS: lipooligosaccharide; CBA: Columbia agar with $5 \%$ sheep blood; CT:
Columbia broth supplemented with $0.1 \%$ Trizma base and $0.01 \%$ thiamine monophosphate; TT: Terrific broth supplemented with $0.1 \%$ Trizma base and $0.01 \%$ thiamine monophosphate; TMP: thiamine monophosphate; CFU, colony forming units; PBS: phosphate buffered saline, pH 7.2; Cetavlon: hexadecyltrimethyl ammonium bromide; PAGE: polyacrylamide gel electrophoresis; ITEM: immuno-transmission electron microscopy; NGS: normal goat serum; SEM: scanning electron microscopy; OdA: O-deacylated; ES-MS: electrospray mass spectrometry; GLC-MS: gas-liquid chromatographymass spectrometry; NMR: nuclear magnetic resonance spectroscopy; ROESY: rotating frame Overhauser enhancement spectroscopy; COSY: correlation spectroscopy; TOCSY: total correlation spectroscopy experiments; DQF-COSY: double quantum filtered correlation spectroscopy; HMBC: heteronuclear multiple bond correlation; HSQC: heteronuclear single quantum coherence; $C_{\text {t: }}$ critical threshold cycle; ABC: ATP-binding cassette; NTHI: nontypable $H$. influenzae.

\section{Acknowledgements and Funding}

This work was funded, in part, by grants 2003-35204-13637 and 2007-3520418338 from the USDA National Research Initiative Competitive Grants Program, and HATCH funds from the Agricultural Experiment Station. We thank Kristin McKeon and Jennifer Larson for technical assistance, and Dr. Jeffrey Weiser and Misha Shchepetov for helpful advice and support for portions of this work. We would like to thank Dr. Shivakumara Siddaramappa for identification of the putative EPS genes in the genome of 2336.

\section{Author details}

${ }^{1}$ Center for Molecular Medicine and Infectious Diseases, Virginia-Maryland Regional College of Veterinary Medicine, Virginia Tech, Blacksburg, Virginia, USA. ${ }^{2}$ Department of Organic Chemistry and Biochemistry University of Naples "Federico II", Italy. ${ }^{3}$ Department of Microbiology, University of lowa, lowa City, IA, USA. ${ }^{4}$ National Research Council, Ontario, Canada. ${ }^{5}$ Division of Pulmonary Medicine, University of Utah School of Medicine, Salt Lake City, UT, USA. ${ }^{6}$ Department of Medicine, Boston University School of Medicine, Boston, MA.

\section{Authors' contributions}

IS carried out the scanning GRT-PCR, electron microscopy, and biofilm studies, TII was responsible for the identification and purification of the EPS and electrophoretic techniques, MAA and JQS carried out the freeze-fracture ITEM and lectin binding studies, AM and CDC carried out analytical and structural analyses of the EPS, ADC and FAM carried out analytical studies on the EPS and LOS, GB carried out preparation of the immune sera, ITEM of EPS on whole cells, and electrophoretic methods. IS, TJI, and AM wrote the manuscript. All authors read and approved the final manuscript.

Received: 17 May 2011 Accepted: 19 August 2011 Published: 19 August 2011 


\section{References}

1. Inzana TJ, Corbeil LB: Haemophilus. In Pathogenesis of bacterial infections in animals.. 3 edition. Edited by: Gyles CLJFP, Songer JG, Thoen CO. Oxford: Blackwell Publishing Ltd; 2004:243-257.

2. Siddaramppa S, Inzana TJ: Haemophilus somnus virulence factors and resistance to host immunity. Anim Health Res Rev 2004, 5:79-93.

3. Corbeil LB, Gogolewski RP, Stephens LR, Inzana TJ: Haemophilus somnus: antigen analysis and immune responses. In Haemophilus, Actinobacillus, and Pasteurella. Edited by: Donachie W, Lainson FA, Hodgson JC. New York: Plenum Press; 1995:63-73.

4. Behling-Kelly $\mathrm{E}$, Vonderheid H, Kim KS, Corbeil LB, Czuprynski CJ: Roles of cellular activation and sulfated glycans in Haemophilus somnus adherence to bovine brain microvascular endothelial cells. Infect Immun 2006, 74:5311-5318.

5. Gogolewski RP, Leathers CW, Liggitt HD, Corbeil LB: Experimental Haemophilus somnus pneumonia in calves and immunoperoxidase localization of bacteria. Vet Pathol 1987, 24:250-256.

6. Mandrell RE, Griffiss JM, Macher BA: Lipooligosaccharides (LOS) of Neisseria gonorrhoeae and Neisseria meningitidis have components that are immunologically similar to precursors of human blood group antigens. $J$ Exp Med 1988, 168:107-126.

7. Mandrell RE, McLaughlin R, Kwaik YA, Lesse A, Yamasaki R, Gibson B, Spinola SM, Apicella MA: Lipooligosaccharides (LOS) of some Haemophilus species mimic human glycosphingolipids, and some LOS are sialylated. Infect Immun 1992, 60:1322-1328.

8. Cox AD, Howard MD, Brisson J-R, Van Der Zwan M, Thibault P, Perry MB, Inzana TJ: Structural analysis of the phase-variable lipooligosaccharide from Haemophilus somnus strain 738. Eur J Biochem 1998, 253:507-516.

9. McQuiston JH, McQuiston JR, Cox AD, Wu Y, Boyle SM, Inzana TJ: Characterization of a DNA region containing 5'-CAAT-3' DNA sequences involved in lipooligosaccharide biosynthesis in Haemophilus somnus. Microb Pathog 2000, 28:301-312.

10. Wu Y, McQuiston JH, Cox A, Pack TD, Inzana TJ: Molecular cloning and mutagenesis of a DNA locus involved in lipooligosaccharide biosynthesis in Haemophilus somnus. Infect Immun 2000, 68:310-319.

11. Howard MD, Cox AD, Weiser JN, Schurig GG, Inzana TJ: Antigenic diversity of Haemophilus somnus lipooligosaccharide: phase-variable accessibility of the phosphorylcholine epitope. J Clin Microbiol 2000, 38:4412-4419.

12. Inzana TJ, Glindemann G, Cox AD, Wakarchuk W, Howard MD: Incorporation of $\mathrm{N}$-acetylneuraminic acid into Haemophilus somnus lipooligosaccharide (LOS): enhancement of resistance to serum and reduction of LOS antibody binding. Infect Immun 2002, 70:4870-4879.

13. Widders PR, Smith JW, Yarnall M, McGuire TC, Corbeil LB: Non-immune immunoglobulin binding of Haemophilus somnus. J Med Microbio/ 1988, 26:307-311.

14. Yarnall M, Gogolewski RP, Corbeil LB: Characterization of two Haemophilus somnus Fc receptors. J Gen Microbiol 1988, 134:1993-1999.

15. Corbeil LB, Blau K, Prieur DJ, Ward ACS: Serum susceptibility of Haemophilus somnus from bovine clinical cases and carriers. J Clin Microbiol 1985, 22:192-198.

16. Gomis SM: Intracellular survival of Haemophilus somnus in bovine blood monocytes and alveolar macrophages. Microb Pathog 1998, 25:227-235.

17. Howard MD, Boone JH, Buechner-Maxwell V, Schurig GG, Inzana TJ: Inhibition of bovine macrophage and polymorphonuclear leukocyte superoxide anion production by Haemophilus somnus. Microb Pathog 2004, 37:263-271.

18. Lederer JA, Brown JF, Czuprynski CJ: "Haemophilus somnus", a facultative intracellular pathogen of bovine mononuclear phagocytes. Infect Immun 1987, 55:381-387.

19. Gomis SM, Godson DL, Beskorwayne T, Wobeser GA, Potter AA: Modulation of phagocytic function of bovine mononuclear phagocytes by Haemophilus somnus. Microb Pathog 1997, 22:13-21.

20. Corbeil LB: Histophilus somni host-parasite relationships. Anim Health Res Rev 2007, 8:151-160.

21. Zekarias B, Mattoo S, Worby C, Lehmann J, Rosenbusch RF, Corbeil LB: Histophilus somni IbpA DR2/Fic in virulence and immunoprotection at the natural host alveolar epithelial barrier. Infect Immun 2010, 78:1850-1858.

22. Sylte MJ, Corbeil LB, Inzana TJ, Czuprynski CJ: Haemophilus somnus induces apoptosis in bovine endothelial cells in vitro. Infect Immun 2001, 69:3:1650-1660.
23. Sylte MJ, Inzana TJ, Czuprynski CJ: Reactive oxygen and nitrogen intermediates contribute to Haemophilus somnus lipooligosaccharidemediated apoptosis of bovine endothelial cells. Vet Immunol Immunopathol 2004, 97:207-217.

24. Sylte MJ, Kuckleburg CJ, Atapattu D, Leite FP, McClenahan D, Inzana TJ, Czuprynski CJ: Signaling through interleukin-1 type 1 receptor diminishes Haemophilus somnus lipooligosaccharide-mediated apoptosis of endothelial cells. Microb Pathog 2005, 39:121-130.

25. Challacombe JF, Duncan AJ, Brettin TS, Bruce D, Chertkov O, Detter JC, Han CS, Misra M, Richardson P, Tapia R, Thayer N, Xie G, Inzana TJ: Complete genome sequence of Haemophilus somnus (Histophilus somni) strain 129Pt and comparison to Haemophilus ducreyi $35000 \mathrm{HP}$ and Haemophilus influenzae Rd. J Bacteriol 2007, 189:1890-1898.

26. Corboz L: Epidemiology of "Haemophilus somnus" infection in cattle: colonial variants of strains isolated from various sources. In Haemophilus, Pasteurella, Actinobacillus. Edited by: Kilian MWF, Biberstein EL. London: Academic Press; 1981:133-142.

27. Stephens LR, Little PB: Ultrastructure of Haemophilus somnus, causative agent of bovine infectious thromboembolic meningoencephalitis. Amer $J$ Vet Res 1981, 42:1638-1640.

28. Miller RJ, Renshaw HW, Evans HW: Haemophilus somnus complex: antigenicity and specificity of fractions of Haemophilus somnus. Am J Vet Res 1975, 36:1123-1128.

29. Sandal I, Hong W, Swords WE, Inzana TJ: Characterization and comparison of biofilm development by pathogenic and commensal Isolates of Histophilus somni. J Bacteriol 2007, 189:8179-8185.

30. Lazar V, Chifiriuc MC: Architecture and physiology of microbial biofilms. Roum Arch Microbiol Immunol 2010, 69:95-107.

31. Inzana TJ, Corbeil LB: Development of a defined medium for Haemophilus somnus from cattle. Am J Vet Res 1987, 48:366-369.

32. Inzana TJ: Purification and partial characterization of the capsular polymer of Haemophilus pleuropneumoniae serotype 5. Infect Immun 1987, 55:1573-1579.

33. Inzana TJ, Iritani B, Gogolewski RP, Kania SA, Corbeil LB: Purification and characterization of lipooligosaccharides from four strains of "Haemophilus somnus". Infect Immun 1988, 56:2830-2837.

34. Dubois M, Hamilton A, Rebers PA, Smith F: Colorimetric method for determination of sugars and related substances. Anal Chem 1956, 28:350-356.

35. Pelkonen S, Häyrinen J, Finne J: Polyacrylamide gel electroporesis of the capsular polysaccharides of Escherichia coli K1 and other bacteria. $J$ Bacteriol 1988, 170:2646-2653

36. Min H, Cowman MK: Combined alcian blue and silver staining of glycosaminoglycans in polyacrylamide gels: application to electrophoretic analysis of molecular weight distribution. Anal Biochem 1986, 155:275-285

37. Inzana TJ, Mathison B: Serotype specificity and immunogenicity of the capsular polymer of Haemophilus pleuropneumoniae serotype 5 . Infect Immun 1987, 55:1580-1587.

38. Inzana TJ: Simplified procedure for preparation of sensitized latex particles to detect capsular polysaccharides: application to typing and diagnosis of Actinobacillus pleuropneumoniae. J Clin Microbiol 1995, 33:2297-2303.

39. Ward CK, Inzana TJ: Resistance of Actinobacillus pleuropneumoniae to bactericidal antibody and complement is mediated by capsular polysaccharide and blocking antibody specific for lipopolysaccharide. $J$ Immunol 1994, 153:2110-2121.

40. Sandal I, Hong W, Swords WE, Inzana TJ: Characterization and comparison of biofilm development by pathogenic and commensal isolates of Histophilus somni. J Bacteriol 2007, 189:8179-8185.

41. Greiner LL, Edwards JL, Shao J, Rabinak C, Entz D, Apicella MA: Biofilm Formation by Neisseria gonorrhoeae. Infect Immun 2005, 73:1964-1970.

42. Leontein K, Lindberg B, Lonngren J, Carlo DJ: Structural studies of the capsular polysaccharide from Streptococcus pneumoniae type 12A. Carbohydr Res 1983, 114:257-266.

43. Lee YC, Ballou CE: Complete structures of the glycophospholipids of mycobacteria. Biochem 1965, 4:1395-1404.

44. Rance M, Sorensen OW, Bodenhausen G, Wagner G, Ernst RR, Wuthrich K: Improved spectral resolution in cosy $1 \mathrm{H}$ NMR spectra of proteins via double quantum filtering. Biochem Biophys Res Commun 1983, 117:479-485 
45. Chomczynski P: A reagent for the single-step simultaneous isolation of RNA, DNA and proteins from cell and tissue samples. Biotechniques 1993, 15:532-537.

46. Inzana TJ: Electrophoretic heterogeneity and interstrain variation of the lipopolysaccharide of Haemophilus influenzae. J Infect Dis 1983, 148:492-499.

47. Loeb MR, Zachary AL, Smith DH: Isolation and partial characterization of outer and inner membranes from encapsulated Haemophilus influenzae type b. J Bacteriol 1981, 145:596-604.

48. Molinaro A, Piscopo V, Lanzetta R, Parrilli M: Structural determination of the complex exopolysaccharide from the virulent strain of Cryphonectria parasitica. Carbohydr Res 2002, 337:1707-1713.

49. Sandal I, Shao JQ, Annadata S, Apicella MA, Boye M, Jensen TK, Saunders GK, Inzana TJ: Histophilus somni biofilm formation in cardiopulmonary tissue of the bovine host following respiratory challenge. Microbes Infect 2009, 11:254-263.

50. Ryder C, Byrd M, Wozniak DJ: Role of polysaccharides in Pseudomonas aeruginosa biofilm development. Curr Opin Microbiol 2007, 10:644-648.

51. Davies DG, Chakrabarty AM, Geesey GG: Exopolysaccharide production in biofilms: substratum activation of alginate gene expression by Pseudomonas aeruginosa. Appl Environ Microbiol 1993, 59:1181-1186.

52. Falsetta ML, McEwan AG, Jennings MP, Apicella MA: Anaerobic metabolism occurs in the substratum of gonococcal biofilms and may be sustained in part by nitric oxide. Infect Immun 2010, 78:2320-2328.

53. Clark VL, Campbell LA, Palermo DA, Evans TM, Klimpel KW: Induction and repression of outer membrane proteins by anaerobic growth of Neisseria gonorrhoeae. Infect Immun 1987, 55:1359-1364.

54. Vinogradov E, Petersen B, Bock K: Structural analysis of the intact polysaccharide mannan from Saccharomyces cerevisiae yeast using $1 \mathrm{H}$ and 13C NMR spectroscopy at 750 MHz. Carbohydr Res 1998, 307:177-183.

55. Howard MD, W L, Wakarchuk W, St. Michael F, Cox A, Horne WT, Hontecilas R, Bassaganya-Riera J, Lorenz E, Inzana TJ: Genetics and molecular specificity of sialylation of Histophilus somni lipooligosaccharide (LOS) and the effect of LOS sialylation on Toll-like receptor-4 signaling. Vet Microbiol 2011.

56. Ram S, Sharma AK, Simpson SD, Gulati S, McQuillen DP, Pangburn MK Rice PA: A novel sialic acid binding site on factor $\mathrm{H}$ mediates serum resistance of sialylated Neisseria gonorrhoeae. J Exp Med 1998, 187:743-752.

57. Figueira MA, Ram S, Goldstein R, Hood DW, Moxon ER, Pelton SI: Role of complement in defense of the middle ear revealed by restoring the virulence of nontypeable Haemophilus influenzae siaB mutants. Infect Immun 2007, 75:325-333

58. Swords WE, Moore ML, Godzicki L, Bukofzer G, Mitten MJ, VonCannon J: Sialylation of lipooligosaccharides promotes biofilm formation by nontypeable Haemophilus influenzae. Infect Immun 2004, 72:106-113.

59. Greiner LL, Watanabe H, Phillips NJ, Shao J, Morgan A, Zaleski A, Gibson BW, Apicella MA: Nontypeable Haemophilus influenzae strain 2019 produces a biofilm containing $\mathrm{N}$-acetylneuraminic acid that may mimic sialylated O-linked glycans. Infect Immun 2004, 72:4249-4260.

60. Jurcisek J, Greiner L, Watanabe H, Zaleski A, Apicella MA, Bakaletz LO: Role of sialic acid and complex carbohydrate biosynthesis in biofilm formation by nontypeable Haemophilus influenzae in the chinchilla middle ear. Infect Immun 2005, 73:3210-3218.

61. Hood DW, Makepeace K, Deadman ME, Rest RF, Thibault P, Martin A, Richards JC, Moxon ER: Sialic acid in the lipopolysaccharide of Haemophilus influenzae: strain distribution, influence on serum resistance and structural characterization. Mol Microbiol 1999, 33:679-692.

62. Jackson KD, Starkey M, Kremer S, Parsek MR, Wozniak DJ: Identification of $p s l$, a locus encoding a potential exopolysaccharide that is essential for Pseudomonas aeruginosa PAO1 biofilm formation. J Bacteriol 2004, 186:4466-4475.

63. Byrd MS, Sadovskaya I, Vinogradov E, Lu H, Sprinkle AB, Richardson SH, Ma L, Ralston B, Parsek MR, Anderson EM, Lam JS, Wozniak DJ: Genetic and biochemical analyses of the Pseudomonas aeruginosa Psl exopolysaccharide reveal overlapping roles for polysaccharide synthesis enzymes in Psl and LPS production. Mol Microbiol 2009, 73:622-638.

64. lida A, Harayama S, lino T, Hazelbauer GL: Molecular cloning and characterization of genes required for ribose transport and utilization in Escherichia coli K-12. J Bacteriol 1984, 158:674-682.
65. Mollerach M, Lopez R, Garcia E: Characterization of the galU gene of Streptococcus pneumoniae encoding a uridine diphosphoglucose pyrophosphorylase: a gene essential for capsular polysaccharide biosynthesis. J Exp Med 1998, 188:2047-2056.

66. Wong SM, Akerley BJ: Environmental and genetic regulation of the phosphorylcholine epitope of Haemophilus influenzae lipooligosaccharide. Mol Microbiol 2005, 55:724-738.

doi:10.1186/1471-2180-11-186

Cite this article as: Sandal et al:: Identification, structure, and characterization of an exopolysaccharide produced by Histophilus somni during biofilm formation. BMC Microbiology 2011 11:186.

\section{Submit your next manuscript to BioMed Central and take full advantage of:}

- Convenient online submission

- Thorough peer review

- No space constraints or color figure charges

- Immediate publication on acceptance

- Inclusion in PubMed, CAS, Scopus and Google Scholar

- Research which is freely available for redistribution

Submit your manuscript at www.biomedcentral.com/submit
C Biomed Central 